\title{
Molecular mechanisms controlling brain development: an overview of neuroepithelial secondary organizers
}

\author{
CLAUDIA VIEIRA, ANA POMBERO, RAQUEL GARCÍA-LOPEZ, LOURDES GIMENO, \\ DIEGO ECHEVARRIA and SALVADOR MARTÍNEZ*
}

Alicante Neuroscience Institute, Miguel Hernandez University, CSIC, San Juan de Alicante, Alicante, Spain

\begin{abstract}
The vertebrate Central Nervous System (CNS) originates from the embryonic dorsal ectoderm. Differentiation of the neural epithelium from the ectoderm and the formation of the neural plate constitute the first phase of a complex process called neurulation which culminates in the formation of the neural tube, the anlage of the CNS in sauropsids and mammals (for review see Smith and Schoenwolf, 1997; Colas and Schoenwolf, 2001). At neural plate and neural tube stages, local signaling centers in the neuroepithelium, known as secondary organizers, refine the antero-posterior specification of different neural territories (for review see Echevarria et al., 2003; Stern et al., 2006; Woltering and Durston, 2008). In this review, we will describe the principle aspects of CNS development in birds and mammals, starting from early stages of embryogenesis (gastrulation and neurulation) and culminating with the formation of a variety of different regions which contribute to the structural complexity of the brain (regionalization and morphogenesis). We will pay special attention to the cellular and molecular mechanisms involved in neural tube regionalization and the key role played by localized secondary organizers in the patterning of neural primordia.
\end{abstract}

KEY WORDS: patterning, neural plate, neural tube, gastrulation, neurulation, secondary organizer, anterior neural ridge, zona limitans intrathalamica, isthmic organizer

\section{Neural plate and neural tube formation}

A fundamental early step in neural development is the allocation of a group of ectodermal cells as precursors of the entire nervous system (Hemmati-Brivanlou and Melton, 1997). This process involves an inductive interaction first demonstrated in amphibian embryos by Spemann and Mangold in the 1920's (see Spemann and Mangold, 2001). Their experiments which involved the grafting of differently pigmented species of newt established the concept of neural induction as an instructive interaction between the dorsal lip of the blastopore (the "organizer") and the neighboring ectoderm. The discovery of a neural organization center for the amphibian gastrula initiated a search for homologous structures in other vertebrates. Soon thereafter, the equivalent region was discovered in most vertebrate species, including the shield of teleosts. In birds and mammals, the region was named "Hensen's node" and "the node", respectively. When C.H. Waddington transplanted the Hensen node of a chick embryo, he observed the induction of an ectopic neural plate or the formation of a partial new embryonic axis containing neural tube, notochord and somites (Waddington, 1933; Waddington, 1936). This demonstration provided the first evidence that in chick embryos, the nervous system is induced by signals from non-neural cells. Recent works demonstrated that the capacity of ectodermal cells to undergo neural differentiation represents their default state. In fact, neural differentiation must be suppressed in the lateral ectoderm by signals transmitted between neighboring cells, in order to develop as epidermis. These molecular signals are members of the bone morphogenetic protein (BMP) subclass of transforming growth factor $\beta$ (TGF- $\beta$ )-related proteins (for review see Wittler and Kessel, 2004).

\footnotetext{
Abbreviations used in this paper: ANR, anterior neural ridge; AP, anteroposterior; BMP, bone morphogenetic protein; DV, dorso-ventral; FGF, fibroblast growth factor; IsO, Isthmic organizer; ML, medio-lateral; TGF,
} transforming growth factor; ZLI, zona limitans intrathalamica.

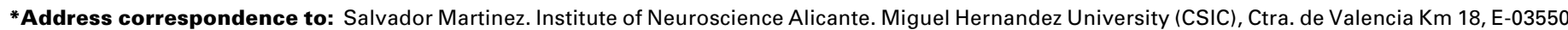
San Juan de Alicante, Alicante, Spain. Fax.+34-965-919-555. e-mail: smartinez@umh.es Tel:+34-965-919-556.

Web: http://www.ina.umh.es/grupos-detalle.aspx?grupo=6
} 


\section{GASTRULATION}

A

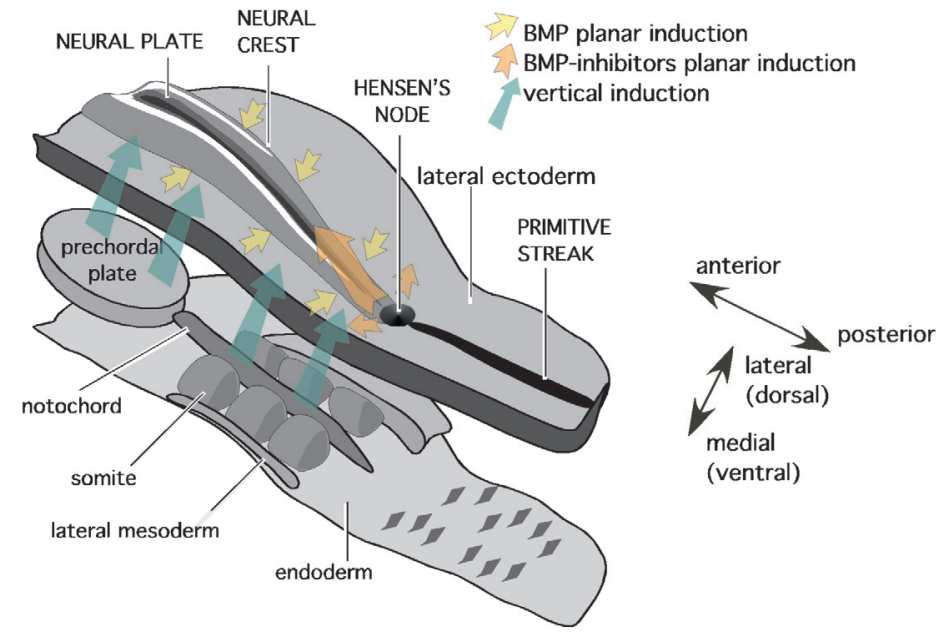

NEURULATION
B

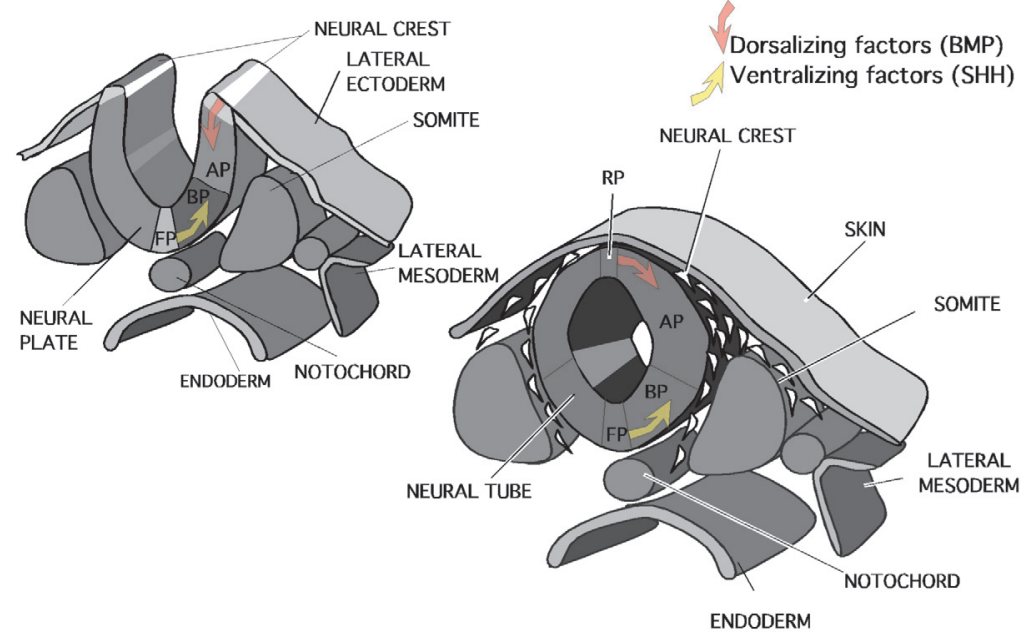

Fig. 1. The neurulation process. (A) At neural plate stage, vertical induction (green arrows) from the underlying axial mesendoderm (notochord and prechordal plate), together with planar induction from Hensen's node (orange arrows) and ectoderm (yellow arrows) regulate dorsoventral polarity and the initial steps of antero-posterior regionalization in the neuroepithelium. (B) During neurulation, neural folds close at the dorsal midline. Neural crests cells delaminate and migrate from the neural folds before closure and the neural grove become the lumen of the neural tube. Planar information from the ventral midline (floor plate; FP; yellow arrow) and dorsal midline (roof plate; RP; red arrow) plays a fundamental role in the establishment of definitive dorsoventral regionalization, using sonic hedgehog (SHH) and bone morphogenetic proteins (BMP) as signaling molecules. As a consequence of these inductive events, the lateral wall of the neural tube is subdivided into two columnar domains: the basal plate (close to the floor plate) and the alar plate (close to the roof plate). AP, alar plate; BP, basal plate.

Recent studies using chick embryos have shown that neural induction really begins prior to the formation of the organizer region and thus must be initiated by signals derived from other cellular areas. Members of other families of signaling molecules, notably the fibroblast growth factors (FGFs), have now been proposed as early-acting factors, which initiate neural induction by a progressive sequence of molecular interactions. First, the presumptive neural plate area is established by Fgf8 activity coming from the primary endoderm. Subsequently, the suppression of BMP signaling maintains rather than initiates the process of neural differentiation (Linker et al. 2009; for review see Stern, 2005).

These molecular interactions together with the participation of Hox genes (Woltering and Durston, 2008; Hooiveld et al., 1999) during the process of gastrulation regulate cellular inductive events leading to the definition of the antero-posterior and dorso-ventral axes of the embryo and to the generation of the three blastodermal layers: ectoderm, mesoderm and endoderm (Stern et al.,2006). Thus, in the central area of the embryo (at its prospective dorsal region), ectoderm cells are induced to develop as neural plate cells as a result of these progressive cellular and molecular interactions, acting via planar and vertical induction (Fig. 1A). Indeed, formation of the neural plate involves apicobasal thickening and pseudostratification of the ectoderm, resulting in the formation of a flat but thickened epithelial region which expresses a unique pattern of molecular markers (Smith and Schoenwolf, 1989; Keller et al., 1992).

Subsequently, the process of neurulation involves cell shape changes and epithelial rearrangement which result in the bending of the neural plate and apposition of its latent edges to form the neural tube. The neural plate lengthens along the anteroposterior axis and becomes narrower, so that subsequent bending will form a tube. Full antero-posterior formation and extension of the neural tube requires normal gastrulation movements and in particular, regression of the primitive streak (Voiculescu et al., 2007).

Bending of the neural plate involves the formation of hinge regions where the neural tube contacts surrounding tissues (for review see Colas and Schoenwolf, 2001). Elevation of the neural folds establishes a trough-like space called the neural groove, which becomes the lumen of the primitive neural tube after closure of the neural groove. In addition, the neural folds will generate the specialized cells of the neural crest. The neural tube closes as the paired neural folds are brought together at the dorsal midline (Fig. 1B). During this stage, the epidermal ectoderm from each fold detaches from its ipsilateral neuroepithelial partner and fuses with the epidermal ectoderm of the contralateral neural fold, contributing to the dorsal skin of the embryo. Similarly the detached neuroepithelial layers from both sides fuse together below the epidermal ectoderm, establishing the roof plate of the neural tube.

\section{Cellular patterns and molecular regionalization of the neu- ral plate}

Experiments involving the labeling of individual cells or small groups of them, and analysis of their fate during gastrulation and neurulation have been performed in different species. The resulting fate maps showed that the generation of the neural plate and tube involves similar morphogenetic programs in 
vertebrates (reviewed by Rubenstein et al., 1998; Cobos et al., 2001). During gastrulation, the bending of the neural plate, together with the intercalation of neuroectodermal precursors and with regional differences in proliferation, transform the initial medio-lateral arrangement of cells in the neural plate into the dorso-ventral organization of the neural tube (Fig. 1; Leikola 1976; Stern et al., 2006).

Gene expression patterns provide insights into the location, onset and developmental consequences of inductive processes, which generate regional specification within the developing brain. They also help to identify the candidate molecules which regulate these processes. During the past two decades, researchers have identified many regulatory genes whose patterns of expression in the embryonic neural plate and tube have yielded important insights into brain regionalization (Shimamura et al., 1995; 1997; Rubenstein et al. 1998; Crossley et al. 2001; Puelles and Rubenstein 2003; Echevarria et al. 2003; Aroca and Puelles, 2005). Interpretation of the expression patterns in terms of the topology of the neural plate axes provides a clearer picture of its molecular regionalization and also contributes to our understanding of how the expression of specific sets of genes in the neuroepithelium is related to brain histogenesis. Thus, longitudinal patterns reflect expression which extends along part or the entire antero-posterior axis and may mark the three primordia of the floor, basal and alar plates (Fig. 2). At the anterior pole of the neural plate, there is evidence indicating that medial (basal plate primordium) and lateral (alar plate primordium) domains form nested arcs which are concentric with the anterior neural ridge (Shimamura et al., 1995; Cobos et al., 2001; Echevarria et al., 2003).

Other genes have expression domains which are restricted to transverse regions of the neural plate, showing molecular discontinuities along the antero-posterior axis (Fig. 2). Interestingly some transcription factors are expressed in nested domains of the neural plate, playing a fundamental role in the establishment of particular transverse territories which actively regulate the development of the neighboring neuroepithelium. These nested domains have been termed secondary organizers (Fig. 2; Martinez, 2001; Echevarria et al., 2003; Aroca and Puelles 2005).

\section{Regionalization of the neural tube}

The early neural tube is, in most vertebrates, a straight structure. However, even before the posterior portion of the tube has formed, the most anterior portion of the neural tube is undergoing drastic changes. In this region, the tube balloons into three primary vesicles: the forebrain (prosencephalon), midbrain (mesencephalon) and hindbrain (rhombencephalon) (Fig. 3; reviewed in Martinez and Puelles, 2000). By the time the posterior end of the neural tube closes, secondary bulges - the optic vesicles - have extended laterally from each side of the developing forebrain. At this early stage of development (three vesicle stage), the bending of the long axis, already observed at the late neural plate stages, increases considerably after neurulation, leading to the cephalic and cervical flexures of the neural tube (Fig. 3). Then, the prosencephalon becomes subdivided into the anterior secondary prosencephalon (telencephalon and hypothalamus) and the more caudal diencephaIon (Pombero and Martinez, 2009).

The discovery that putative regulatory genes are expressed in regionally restricted patterns in the developing forebrain has
A

Fig. 2. Molecular regionalization of the neural plate. Schematic (A) and realistic (B) representations of gene expression domains at the neural plate stage. Different colors represent different genes (gene symbol and color codes are identified in the schematic diagram). Medio-lateral (dorso-ventral) and anteroposterior (rostro-caudal) regionalization are identifiable by the limits between expression domains. The presumptive epithelia of different brain regions have been identified, as well as the presumptive localization of the secondary organizers, in relation to precise boundaries between gene expression domains. Secondary organizers: ANR: anterior neural ridge; ZLI: zona limitans intrathalamica; IsO: isthmic organizer. Longitudinal domains: $R P$, roof plate; $A P$, alar plate: $B P(b p)$, basal plate; $F P$, floor plate. Abbreviations: Hypoth, hypothalamus; prethal, prethalamus tg; thal, thalamus; prerub, prerubral; pretect, pretectum; MES, mesencephaIon; mes tg, mesencephalic tegmentum; r1, rhombomere 1.

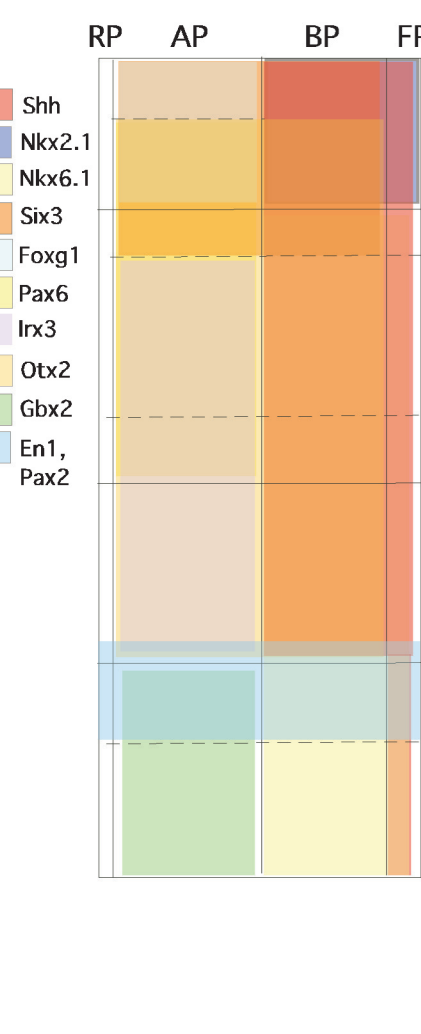

B

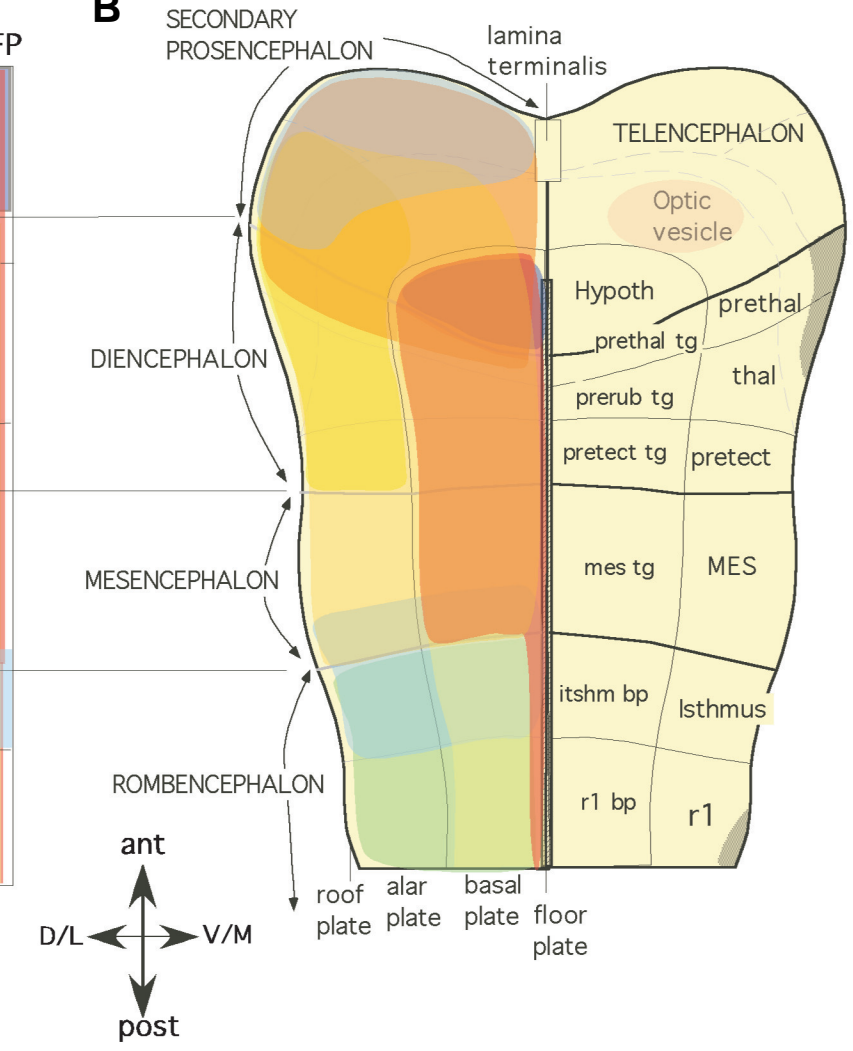


provided new tools for defining histogenic domains and their boundaries at higher resolution. Based on gene expression patterns as well as morphological information, two models have been used to interpret neural plate and tube regionalization: a regional-topographic model, largely aimed at saving the classic concept of sulcal division of the diencephalon into the 4 longitudinal columnar zones of Herrick (Alvarez-Bolado et al. 1995) and a segmental-topological model called the "prosomeric model" (Puelles and Rubenstein, 1993; Rubenstein et al., 1994). The latter is more consistent with emergent morphological, molecular and experimental data on the bent longitudinal forebrain axis, which cannot be satisfactorily rationalized in terms of the zones of Herrick. Although today there are still some authors who do not use the segmental paradigm to interpret gene expression patterns in the developing neural tube, most current studies do follow this prosomeric model, since it has demonstrated more topographic and anatomic accuracy, easily lends itself to comparative analysis and clearly displays higher predictive capacity than other alternatives.

The prosomeric model hypothesizes that the embryonic forebrain is a neuromeric structure subdivided into a grid-like pattern of histogenic domains by longitudinal (columnar) and transverse (segmental) boundaries, as a result of the evolution of the Cartesian organization of the neural plate (Puelles et al., 1987; Bulfone et al., 1993; Puelles and Rubenstein, 1993; Rubenstein and Puelles, 1994; Rubenstein et al., 1994; Shimamura et al., 1995; Puelles, 1995). The longitudinal boundaries segregate columns of cells with similar properties. These are specified by dorso-ventral (DV) patterning mechanisms, which are equivalent to the latero-medial patterning mechanisms of the neural plate. All these interactions, which occur during DV patterning, give rise to four longitudinal columnar territories, which from ventral to dorsal are the floor plate, basal plate, alar plate and roof plate (Fig. 1B).

Transverse boundaries subdivide the brain into segments (neuromeres). In the prosencephalon, these segments are called prosomeres (p1-6; Puelles and Rubenstein, 1993, or in a simplified schema, p1-p3 plus the secondary prosencephaIon, Puelles and Rubenstein, 2003). In the rhombencephalon, the segments are termed rhombomeres (r1-r7) and pseudorhombomeres (r8-r11) (Marin and Puelles, 1995; Cambronero and Puelles, 2000) (Fig. 3). The mesencephalon has not been subdivided into internal sub-segments, and consequently is considered as single segmental unit.

The prosomeric model has unveiled the morphological significance of numerous gene expression patterns in the forebrain, suggesting the existence of additional molecular subdivisions of the main AP and DV zones, representing histogenetically specified domains of neural precursors (Fig. 3; Puelles et al., 1987; Bulfone et al., 1993; Puelles and Rubenstein, 1993; Rubenstein and Puelles, 1994; Rubenstein et al., 1994; Shimamura et al., 1995; Puelles, 1995). Examination of this molecular-structural association has shown how the prosencephalic expression of particular genes is directly related to specific morphogenetic and cytogenetic development. Thus, for instance $G b x 2$ expression is associated with the generation of thalamic neurons which develop into the thalamo-cortical projection (Miyashita-Lin et al., 1999; Hasimoto-Torii et al., 2003), whereas $N k x 2.1$ expression is associated with hypothalamic development (Sussel et al., 1999).

\section{Medio-lateral (ML) / dorso-ventral (DV) patterning}

The specification of longitudinally aligned regions within the
A
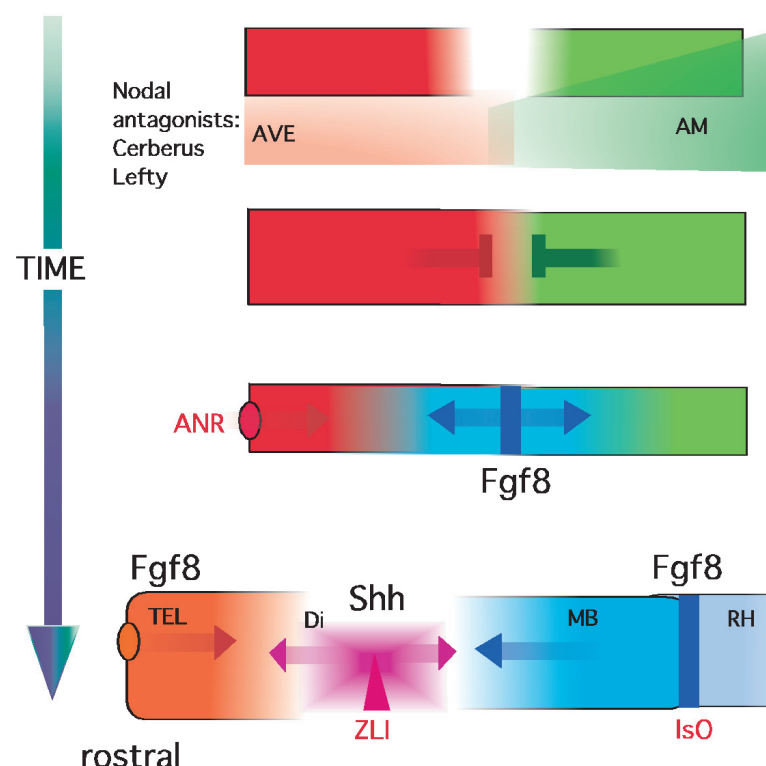

rostral
B E10.5

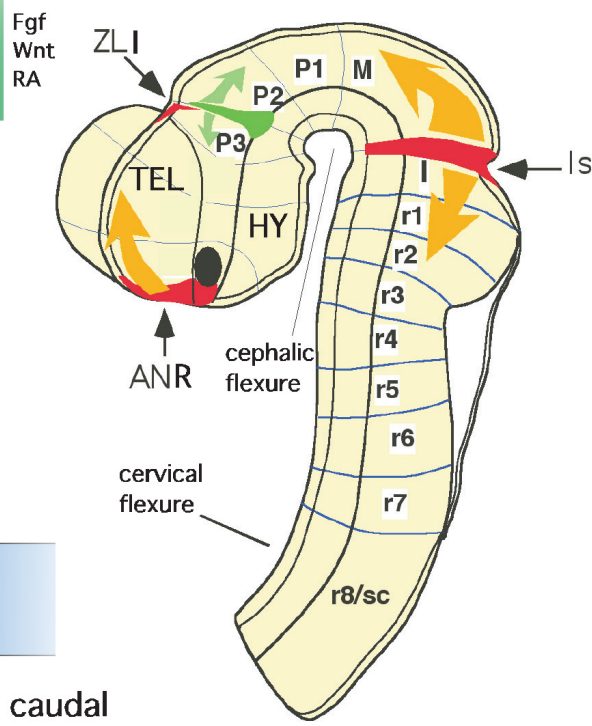

Fig. 3. Secondary organizer specification and neural tube regionalization. (A) Schematic representation of secondary organizer specification in relation to gene expression patterns (color codes) and time (arrow). Morphogenetic signals from the anterior ventral endoderm (AVE) and axial mesendoderm (AM) determine the early establishment of anterior and posterior properties in the neuroepithelium and induce local domains of transcription factor expression in the overlying epithelium. Molecular interactions at the limits between these domains specify the development of morphogenetic organizers that generate a secondary wave of inductive signals (arrows) to regulate the development of structural properties

in the surrounding neural tube regions. (B) Representation of a lateral view of an E10.5 mouse neural tube showing the main neuronal regions and the transverse segments of the neural tube in relation to the secondary organizers. Abbreviations: ANR, anterior neural ridge; AVE, anterior ventral endoderm; AM, axial mesoderm; DI, diencephalon; $M, M B$, midbrain; HY, hypothalamus; I, isthmus; IsO, isthmic organizer; RH, rhombencephalon; TEL, telencephalon; ZLI, zona limitans intrathalamica; p1-p3, prosomeres; r1-r8, rhombomeres; sc, spinal cord. 
CNS involves patterning along the ML dimension of the neural plate. This ML patterning in the neural plate is topologically equivalent to DV patterning in the neural tube (Figs. 1 and 2).

It has been well established that within the posterior neural plate, ML regional identities are specified in part by molecules produced by adjacent non-neural tissues. Both gain- and lossof-function experiments have demonstrated that medial signaling is regulated by Sonic Hedgehog (Shh) produced by the axial mesendoderm (Echelard et al., 1993; Roelink et al., 1994, 1995; Hynes et al., 1995a; Marti et al., 1995; Tanabe et al., 1995; Chiang et al., 1996; Ericson et al., 1996; Shimamura and Rubenstein, 1997; for review see Tanabe and Jessel, 1996). Shh is first produced by the notochord, and later its expression is induced in the overlying medial neural plate (Fig. 1A). Moreover, gain-of-function experiments and gene expression data support the idea that lateral signaling is regulated by members of the TGF- $\beta$ superfamily, such as BMP4 and BMP7 produced by non-neural ectoderm (Basler et al., 1993; Dickinson et al., 1995; Liem et al., 1995; Shimamura and Rubenstein, 1997). Because the notochord does not underlie the anterior forebrain (the anterior end of the notochord ends at the level of the anterior diencephalon at the prethalamic basal plate), it is unclear if patterning of the medial (ventral) forebrain is regulated by mechanisms distinct from those which occur in more posterior regions. Anterior to the notochord, an axial mesendodermal structure named the prechordal plate underlies the anterior part of the floor plate. Several lines of molecular and genetic evidence now suggest that medial/ventral specification of the forebrain is regulated by the prechordal plate and involves molecular mechanisms similar to those in more posterior CNS regions. In fact, analysis of mice lacking a functional Shh gene has demonstrated that Shh is essential for medial patterning of the entire CNS (Chiang et al., 1996). In a study reported by Rubenstein and Shimamura (1997) using a neural plate explant method, the authors directly show that the prechordal plate (and the dorsal foregut) induces medial properties and represses lateral properties in prosencephalic explants (Shimamura and Rubenstein, 1997). Furthermore, they showed that the prechordal plate functions alone in the initial specification of the medial prosencephalon.

Thus, the prechordal plate and notochord share similar roles in medial neural plate specification and longitudinal neural patterning. However, they also exhibit distinct molecular properties which may endow them with specific inductive abilities (Placzek et al., 1993) which contribute to different properties in the overlying prechordal and epichordal basal plates. In fact, we recently demonstrated that diencephalic epichordal and prechordal basal plates have different inductive properties when ectopically grafted into the thalamus or telencephalon (Vieira et al. 2006).

\section{Antero-posterior (AP) patterning}

AP patterning is the process that leads to the generation of distinct transverse domains at different axial positions in the CNS. There is evidence that AP patterning begins during early gastrulation.

We have previously described how several experiments suggest that vertical signals from underlying tissues (meso- derm and endoderm) to the overlying dorsal ectoderm, and perhaps planar signals from the organizer (Hensen's node) through the plane of the ectodermal epithelium, contribute to the specification of AP regional differences (Fig. 1; for review see Doniach 1993; Ruiz i Altaba, 1994). The initial AP pattern is induced by the combined action of two signals produced by the dorsal mesoderm (for review see Doniach, 1993). The first signal initiates neural development and induces the neuroectoderm, which has an anterior neural fate (forebrain and midbrain). Candidate molecules to regulate this signal are Lim1 and Otx2, while a candidate signal is the protein Cerberus (see below). A graded second signal then posteriorizes the neural plate, inducing hindbrain and spinal cord development. Candidate signals for the posteriorizing signal include retinoic acid (Durston et al., 1989; Papalopulu et al., 1991; Ruiz I Altaba and Jessell, 1991a, b; Blumberg et al., 1997) basic FGF (FGF2; Cox and Hemmati-Brivanlou, 1995; Kelly and Melton, 1995; Lamb and Harland, 1995; Hemmati-Brivanlou and Melton, 1997) and Hox genes. In mammals, this latter gene family comprises 39 closely related genes for homeodomain transcription factors, organized in 4 homologous clusters (A, B, C, D) (Pearson et al., 2005). The Hox genes have sharply defined anterior expression boundaries but their posterior boundaries are typically less clear and overlap with the expression of more posterior Hox genes (Hooiveld et al., 1999).

In addition to signals acting during gastrulation, several groups including those of Janet Rossant and Siew-Lan Ang found that mesendodermal tissues underlying the anterior neural plate could regulate regional patterns of gene expression (e.g. Orthodenticle (Otx2) and Engrailed (En1)) within the rostral brain (Ang and Rossant, 1993; Ang et al., 1994). Moreover Darnell and Schoenwolf (1997) showed that regionally restricted vertical signals are capable of inducing neuroectoderm from naive tissue, and of patterning epiblast to express some mesencephalic/rhombencephalic markers. Recently we have demonstrated the requirent of prechordal mesoderm to develop normal regionalization of the ventral prosencephalon (Garcia-Calero et al., 2008). One protein that may regulate this process is named Cerberus. This secreted protein is expressed in a broad anterior domain flanking the expression of Chordin and Lim1 in the prechordal plate. Thus, Cerberus may specify antero-lateral structures, such as anterior axial mesendoderm (prechordal plate) and would then regulate medial specification within the prosencephalic neural plate. When Cerberus is ectopically expressed in Xenopus embryos, it induces nearly complete head structures (Bouwmeester et al., 1996). Other proteins such as Noggin, Follistatin, Cripto and Chordin also induce anterior neural tissues, but these genes may not be essential for AP patterning (Liguori et al., 2003 and 2009; Lamb et al., 1993; Hemmati-Brivanlou et al., 1994; Lamb and Harland, 1995; for review see Doniach, 1993).

Two homeodomain transcription factors, Lim1 and Otx2, are expressed in the tissues underlying the anterior neural plate and seem to be essential for the development of anterior CNS structures. Loss-of-function mutants result in mouse embryos lacking forebrain and midbrain, suggesting that Lim1 and Otx2 have a role in early AP patterning (Acampora et al., 1995; Matsuo et al., 1995; Shawlot and Behringer, 1995; Ang et al., 1996). Lim1 is expressed in the primitive streak and prechordal 
mesoderm. Because expression is not detected in the neural plate, the lack of forebrain and midbrain in Lim1 mutants is evidence for an essential role of this mesoderm in anterior CNS development (Shawlot and Behringer, 1995). Understanding the mechanisms underlying the Otx2 phenotype is more difficult because of the dynamics of its expression pattern and the complexity of its molecular interactions.

$A$ variety of evidence indicates that $A P$ regionalization can generate transverse blocks of neuroepithelium which have distinct competence to respond to the same inductive signal (Ericson et al., 1995; Hynes et al., 1995b; Simon et al., 1995; Shimamura and Rubenstein, 1997). This phenomenon is clearly illustrated by inductive responses to Shh. Shh is expressed along the entire AP extent of the prechordal plate and the notochord. Whereas Shh induces the expression of some genes (e.g. Shh, HNF3 $\beta, N k x 2.2$ ) in all regions of the medial neural plate/ventral neural tube, other genes are induced within particular intervals along the AP axis. For instance, whereas $N k x 2.1$ is expressed only in the prosencephalic neural plate, Nkx6.1 is expressed in more posterior locations (Qiu et al., 1998). Thus, available evidence suggests that in some cases, distinct gene expression programs at different AP positions within the medial neural plate are due to intrinsic differences in competence to respond to a common signal.

Fgf8 is another example of an inductive signal which generates distinct molecular responses at different axial levels. When Fgf8 is applied to prosencephalic and mesencephalic domains of neural plate explants, it induces distinct genes: anteriorly, it induces FoxG1 (Bf1), whereas posteriorly, it induces En2 (Shimamura and Rubenstein, 1997).

\section{Regionalization of the rostral brain involves signal- ing from secondary organizing centers}

Regionalization of the anterior neural plate appears to result from the superposition of multiple distinct patterning mechanisms. AP patterning creates transverse zones, each with a distinct histogenic competence, while patterning along the $M L$ axis generates longitudinally aligned domains. The combination of ML and AP patterning then generates a grid-like organization of distinct brain region primordia (see Fig. 2). Therefore, neural progenitors in the epithelium will establish their differen-

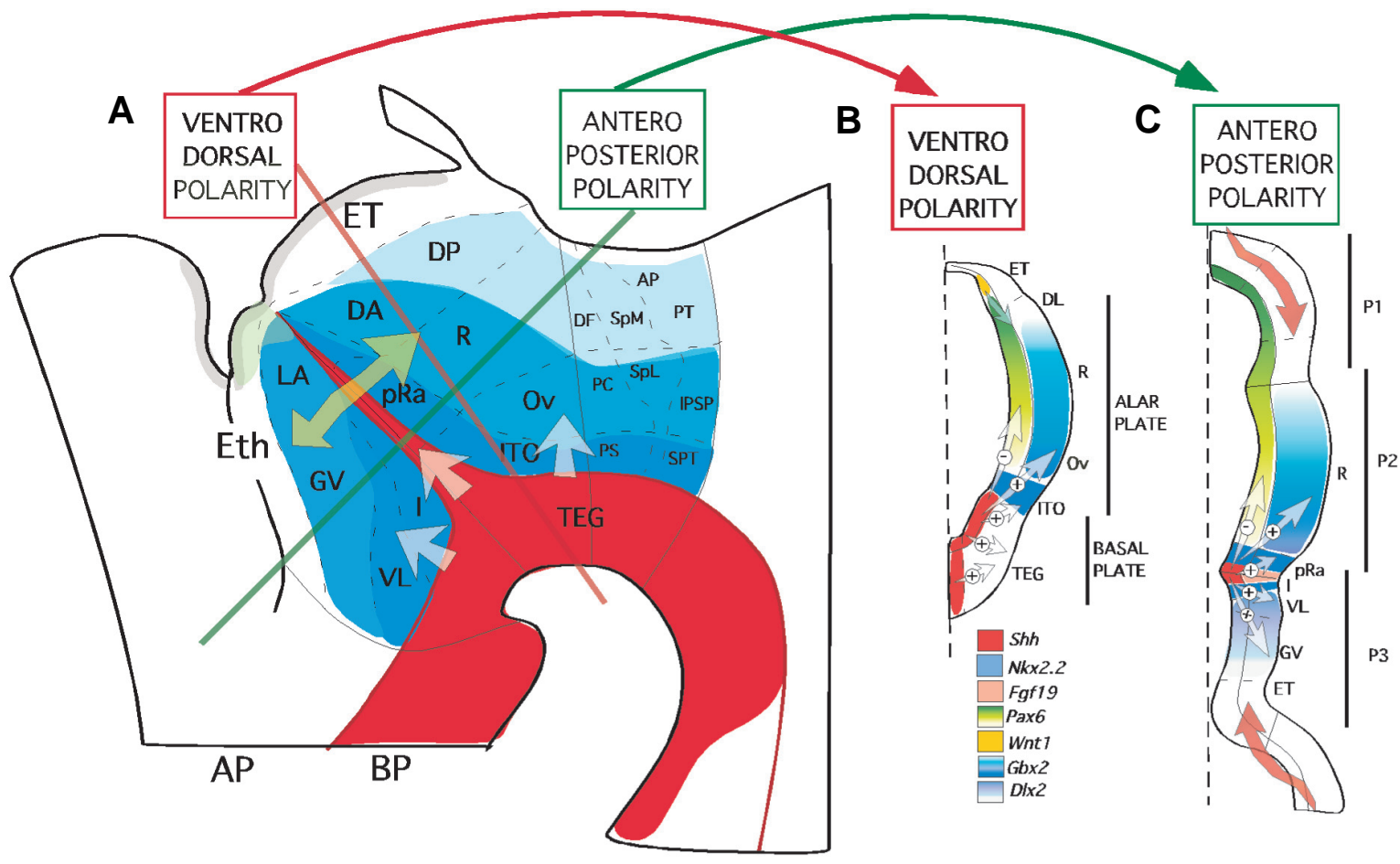

Fig. 4. Shh signal activity and diencephalic regionalization. Schematic representation illustrating the diencephalic regionalization and its relation with thalamic and prethalamic gene markers. Shh morphogenetic activity has a gradient effect in the diencephalic alar plate that could influence ventrodorsal and antero-posterior regionalization. Shh morphogenetic gradient from the basal plate and from the ZLI, represented by graded blue colors, control the expression of diencephalic selector genes (represented by color fields) and is fundamental for the correct specification of the diencephalic regions. The arrows are showing inductive interactions of the morphogenetic signals. Diagrams of transversal (dorso-ventral polarity) and horizontal (antero-posterior polarity) section planes in the diencephalon are represented to the right of the figure. White arrows represent Shh inductive (+) and repressive (-) effects, light blue arrow represent Wnt1 activity from dorsal midline, and light red arrows represent Fgf8 signals from the Isthmus and the anterior neural ridge. Abbreviations: AP, area pretectalis; DA, dorsomedial thalamic complex; DF, dorsofrontal nucleus; DP, dorsolateral thalamic complex; ET, epithalamus; Eth, eminentia thalamica; GV, lateral geniculate nucleus; I, nucleus intercalatus; IPSP, interstitial pretectal-subpretectal nucleus; ITO, interstitial nucleus of the optic tract; LA, anterior lateral nucleus; Ov, nucleus ovoidalis; P1, prosomer 1; P2, prosomer 2; P3, prosomer 3; $P C$, principal precommissural nucleus; $p R A$, perirotundic area; $P S$, superficial precommissural nucleus; $P T$, principal pretectalis nucleus; $R$, rotundus nucleus; SpL, lateral spiriformis nucleus; SpM, medial spiriformis nucleus; SPT, subpretectal nucleus; TEG, diencephalic tegmentum; VL, ventrolateralis nucleus. 
tiation program under the control of positional information (as defined in a Cartesian-type map) transmitted by molecular signals.

Distinct neural and glial identities are acquired by neuroepithelial cells through progressive restriction of histogenetic potential under the influence of local environmental signals. Evidence for morphogenetic controlling processes at specific locations of the developing neural primordium has led to the concept of secondary organizers, which regulate the identity and regional polarity of neighboring neuroepithelial regions (Fig. 3, Ruiz i Altaba, 1998; for review see Martinez, 2001; Echevarria et al., 2003). Thus, these organizers, secondary to those that operate throughout the embryo during gastrulation, usually develop within the previously broadly regionalized neuroectoderm at given genetic boundaries (frequently where cells expressing different transcription factors are juxtaposed) and their subsequent activity refines local neural identities along the AP or DV axes, patterning the anterior neural plate and neural tube, giving rise to the forebrain, midbrain and hindbrain vesicles (Meinhardt, 1983; Figdor and Stern, 1993; Wassef and Joyner, 1997; Rubenstein et al., 1998; Joyner et al., 2000).

Three regions in the neural plate and tube have been identified as putative secondary organizers (Fig. 3): the anterior neural ridge (ANR) at the anterior end of the neural plate/tube, the zona limitans intrathalamica (ZLI) in the middle of the diencephalon and the isthmic organizer (IsO) at the mid-hindbrain boundary.

\section{Anterior neural ridge (ANR)}

The anterior secondary organizer, the ANR, was first described by Houart el al. (1998) in zebrafish at the junction between the most rostral part of the neural plate, the anlage of the anterior commissure and non-neural ectoderm. Genes expressed in this region control others necessary for telencephalic regionalization (Shimamura and Rubenstein, 1997; Ye et al., 1998). In particular, the Fgf8 gene is expressed very early in ANR cells and has been shown to be crucial for the specification of the anterior areas of the forebrain and telencephalon. Fgf8 expression in the ANR is necessary for the induction and/or maintenance of FoxG1 (Bf1) expression, which in turn is essential for telencephalic precursor proliferation (Xuan et al., 1995; Shimamura and Rubenstein, 1997). In addition, implantation of Fgf8 protein into the prospective area of the telencephalon in chick embryos generates changes in the patterns of gene expression and consequently a redistribution of telencephalic and optic derivatives (Crossley et al., 2001). Ectopic expression of Fgf8 in the caudal telencephalon of mouse embryos produces duplication of functional areas of the cortex (Fukuchi-Shimogori and Grove, 2001). Fgf8 regulates prosencephalic regionalization, at least in part, through inhibition of Otx2 and Emx2 expression and cooperation with Bmp4, Wnt and Shh (Fig. 5; Crossley et al., 2001; Garel et al., 1997; Storm et al., 2006). Recently, other member of the FGF family, such as Fgf15, is expressed in the ANR. Its expression domain is closely related with that of Fgf8 and its expression seems to be induced by Fgf8 protein (Gimeno et al., 2002, 2003).

Another signaling protein secreted near the ANR is Shh. Considerable evidence suggests that Shh is both necessary and sufficient for the specification of ventrality throughout the nervous system, including the telencephalon (Echelard et al., 1993; Chiang et al., 1996; Hammerschmidt et al., 1997; Wijgerde et al., 2002). Moreover, normal patterning in the telencephalon depends on the ventral repression of Gli3 function by Shh and, conversely on the dorsal repression of Shh signaling by Gli3 (Rallu et al., 2002). Finally, the activity of $N k x 2.1$, a homeodomain gene required for the development of the hypothalamus and ventral forebrain (Ericson et al., 1995; Brand et al., 1996) is also regulated by Shh.

\section{Zona limitans intrathalamica (ZLI)}

The diencephalon is a cerebral region, which develops from the caudal prosencephalon. The diencephalic territory is subdivided into three segments, which are transverse domains defined on the basis of morphological and molecular criteria. These are, from caudal to rostral, prosomeres 1 to 3 (Puelles and Rubenstein, 2003; Garcia-Lopez et al. 2004). The alar plate of the first diencephalic prosomere ( 1 1) contains the presumptive pretectal region. Prosomere 2 alar plate develops into the thalamus, while p3 alar plate develops into the prethalamus. The limit between p2 and p3 is called the zona limitans intrathalamica (ZLI; reviewed in Martinez and Puelles, 2000). This intrathalamic limit appears early on in neural tube development and exhibits a unique pattern of molecular expression, which suggests an important role for this area as a secondary morphogenetic organizer in diencephalic histogenesis (Kiecker and Lumsden, 2004; for review see: Echevarria et al., 2003).

The cellular and molecular mechanisms which regulate positioning and specification of the ZLI could be explained in terms of the interaction between prechordal and epichordal neuroepithelia (Figs. 2 and 3). This pre-epichordal planar interaction in the alar plate would induce the conditions which permit the expression of Shh in the ZLI and would activate the morphogenetic properties of this organizer, specifying in turn the compartmentalization and cell fate of the different diencephalic prosomeres, through the control of specific gene expression (Fig. 4; Kobayashi et al., 2002; Vieira et al., 2005). The pattern of Shh expression in the ZLI is very dynamic in both mouse and chick embryos (Echelard et al., 1993; Shimamura et al., 1995; Fig. 3A in Echevarria et al., 2001). It starts by being limited to the diencephalic basal plate and then extends dorsally into the basal part of the presumptive ZLI epithelium, by a process of homogenetic induction. The importance of Shh expression in the ZLI is supported by the fact that mice, which bear mutant Shh, show defects in early development, with an important reduction in size of the diencephalic vesicle (Chiang et al., 1996; Ishibashi and McMahon, 2002).

Cellular identity in the diencephalon may be under the control of genes whose expression is regulated by signaling cascades activated by ZLI-derived morphogens. Nested within the Shh expression domain, ZLI cells express the transcription factor Sim1 (Fan et al., 1999). At both rostral and caudal sides of the ZLI, Nkx2.2 and Fgf15 are expressed (Fig. 4B and C; Price et al., 1992; Shimamura et al., 1995; Gimeno et al., 2002). The Gbx2 transcription factor is expressed caudal to the ZLI and serves as a marker for the thalamus (Martinez-de-la-Torre et al., 2002). Dlx2 and Nkx2.1 are expressed in the alar and basal plate, respectively, just rostral to the ZLI (Gonzalez et al., 
2002). Also, the dorsal end of Shh expression in the ZLI is flanked by Wnt1 caudally (McMahon and Bradley, 1990; Thomas and Capecchi, 1990) and Fgf8 rostrally (Crossley and Martin, 1995; Marti et al., 1995; Crossley et al., 1996).

Recent experimental data from our group demonstrated that Shh signal from both the ZLI and the basal plate play an important role in the molecular patterning of the diencephalic alar plate (Fig. 4A; Vieira et al., 2006). Basal plate signals could play an initial role in the specification of longitudinal territories in the thalamic area (ventro-dorsal patterning; Fig. 4B), while posterior development of the $\mathrm{ZLI}$ represents an additional source of morphogenetic signals which superimpose antero-posterior information over thalamic epithelium (Fiure 4C). The combinatory effects of these two types of information could contribute to the complexity of thalamic molecular regionalization and as a consequence, to its complex anatomy.

\section{The Isthmic organizer (IsO)}

The IsO is localized at the mid-hindbrain transition and controls midbrain and anterior hindbrain regionalization (Fig. 3 and 5; Martinez and Alvarado-Mallart, 1989; for review see Martinez, 2001; Echevarria et al., 2003; Hidalgo-Sanchez et al., 2005; Aroca and Puelles 2005, Partanen 2007). Numerous experimental studies have demonstrated the morphogenetic properties of this region and its role in the specification and normal development of cerebellar, isthmic and mesencephalic territories. The isthmic organizer is critical for the development of adjacent regions (Martinez and Alvarado-Mallart, 1990; Alvarado-Mallart, 1993; Marin and Puelles, 1994), even when transplanted ectopically to rostral regions of the neural tube (Marin and Puelles, 1994; Martinez et al., 1991; Martinez et al., 1995).

Analysis of Fgf8 expression in the mid-hindbrain region allows one to follow the development of the IsO, which occurs at the limit

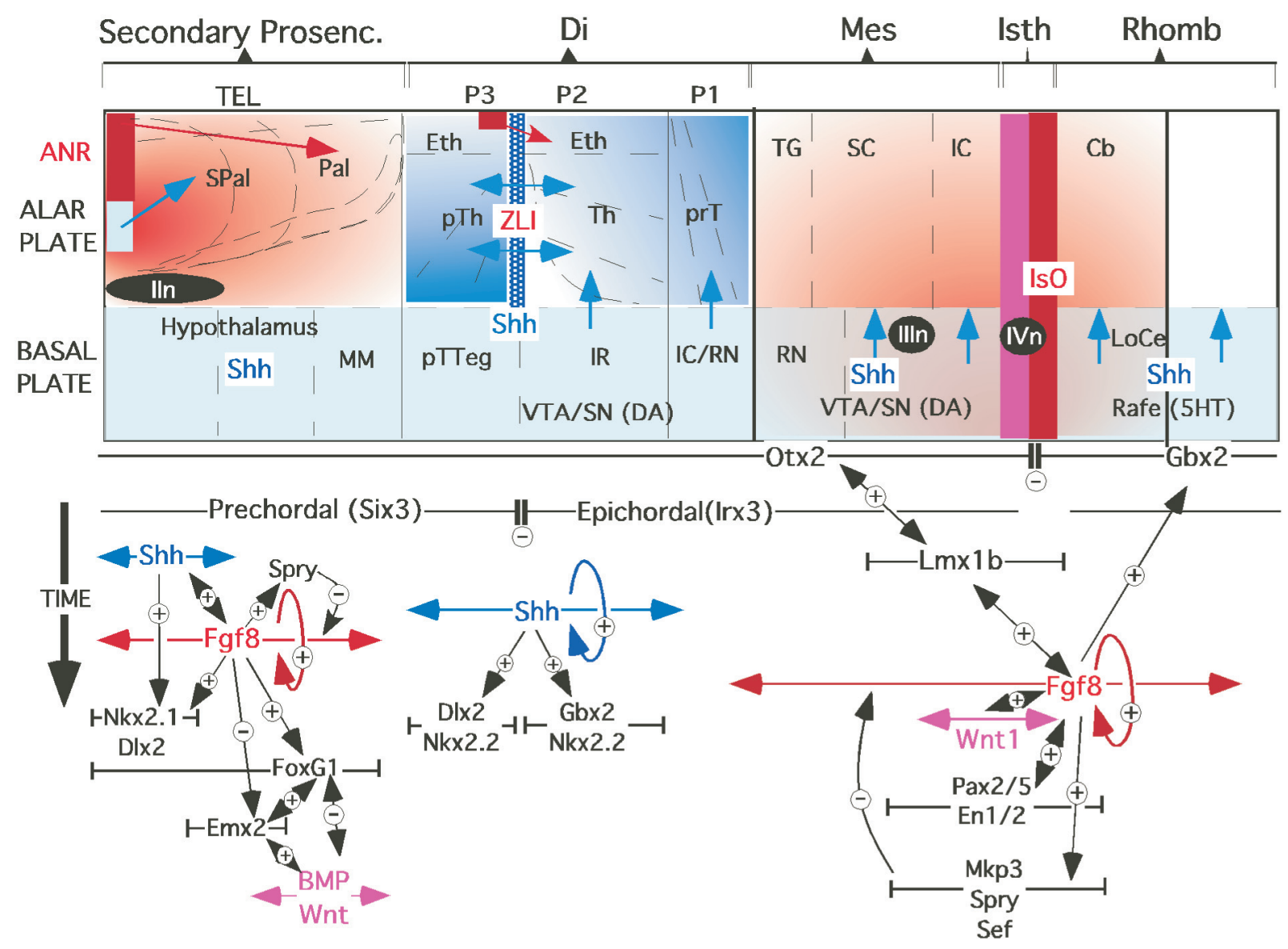

Fig. 5. Molecular pathways controlling brain regionalization. A schematic diagram showing the neural territories influenced by the morphogenetic activity of secondary organizers ( $A N R$, left; $Z L I$, middle and IsO, right; anterior is to the right). The molecular pathways regulating organizer specification are also shown, together with specific local activity associated with the gradient of the signaling molecules (color gradients). Genetic patterns are represented by their respective symbols inside a lineal sector. This sector ends in a vertical line when the gene is a transcription factor or in an arrowhead when the gene encodes a secreted molecule (signaling molecule). Gene interactions are represented by arrows showing the direction of the interaction and inductive (+) or repressive (-) effects. Abbreviations: ANR, anterior neural ridge; Cb, cerebellum; DI, diencephalon; Eth, eminentia thalami; IC, inferior colliculus; IC/RN, Interstitial of Cajal and parvocellular-red nuclei; IR, interstitial rostral nucleus; Is, isthmus; IsO, isthmic organizer; LCe, locus coeruleus; MES, mesencephalon (midbrain); MM, mammillary region; Pal, pallium; pT, prethalamus; pTTeg, prethalamic tegmentum; rafe, rafe nuclei (5HT, serotoninergic cells); RHOMB, rhombencephalon; RN, magnocellular-red nucleus; SC, superior colliculus; Sec. PROS, secondary prosencephalon; SPal, subpallium; T, thalamus; TEL, telencephalon; TG, tectal grey nucleus; VTA/SN, ventral tegmental area/substantia nigra (DA, dopaminergic cells); ZLI, zona limitans intrathalamica; IIIn, 3rd oculomotor nucleus; IVn, $4^{\text {th }}$ trochlear nucleus. 
of expression of Otx2 and Gbx2 domains (Broccoli et al., 1999; Millet et al., 1999; Katahira et al., 2000; Garda et al., 2001; Li and Joyner, 2001; Martinez-Barbera et al., 2001). At early neural stages, Otx2 and Gbx2are, for a short period of time, co-expressed in a domain at their respective interfaces of expression, having an intracellular or intercellular (Fig. 3; Prochiantz, 1999) molecular repressive interaction. Otx2 is quickly down-regulated, being limited to the posterior part of the mesencephalon, whereas the expression of $G b x 2$ is restricted to the isthmus and rhombencephaIon (Millet et al., 1999; Garda et al., 2001). The isthmic organizer develops exactly at the limit between Otx2 and Gbx2 expression domains, suggesting that this cellular interaction at the expression boundary could be essential to specify or stabilize the position of the organizer. Loss of Gbx2 function (Wassarman et al., 1997; Broccoli et al., 1999) or reduction of Otx2 (Acampora et al., 1997; Millet et al., 1999) in mice shows a re-patterning phenotype in the mid-hindbrain regions.

Between the caudal and rostral limits of Otx2 and Gbx2, respectively, Fgf8 expression is induced (Fig. 3 and 5). This neuroepithelial region also dynamically expresses $L m x b 1$ which is required for Fgf8 expression and thus for the development of the isthmic organizer (Guo et al., 2007). Moreover, approximately at the end of gastrulation, Pax2, Pax5, En1 and Wnt1 are each expressed in a transverse domain which coincides with the contact area between Otx2 and Gbx2, and subsequently with the IsO, but in a domain which is broader than that of Fgf8(Fig. 5; Davis and Joyner, 1988; Bally-Cuif et al., 1999; Joyner, 1996; Urbanek et al., 1997; Funashashi et al., 1999; Hidalgo-Sanchez et al., 2000; Rowitch et al., 1999; Hidalgo-Sanchez and Alvarado-Mallart, 2002).

The morphogenetic activity of the isthmic neuroepithelial region was first suggested by loss-of-function experiments centered on the Wnt1 gene (McMahon and Bradley, 1990; Thomas and Capecchi, 1990) and was experimentally demonstrated by using quail-chick grafts of the isthmic neuroepithelium in anterior mesencephalic and diencephalic regions (Martinez et al., 1991). Fgf8 was later reported to be the signal molecule associated with isthmic activity (Crossley et al., 1996). Ectopic Fgf8 protein can induce IsOcharacteristic and structural alterations in the diencephalic caudal prosomeres (p1-p2), the midbrain and the hindbrain (Fig. 5; Crossley et al., 1996; Martinez et al., 1999; Irving and Mason, 2000).

Experimental manipulations of these genes expressed in the IsO have demonstrated that both the presence of their protein products and their normal combined patterns of expression are required for the normal morphogenetic process. Mutant mice lacking Wnt1, Pax2, En1, Gbx2 or Fgf8 do not develop isthmocerebellar structures (McMahon and Bradley, 1990; Millen et al., 1994; Wurst et al., 1994; Urbaneck et al., 1997; Wassarman et al., 1997; Meyers et al., 1998). In addition, experiments involving mutations of En1/2 (Liu and Joyner, 2001), Pax2/5 (Joyner, 1996; Urbanek et al., 1997), Otx1/2 (Matsuo et al., 1995; Suda et al., 1996; Acampora et al., 1997) and a hypomorphic allele for the Fgf8 gene (Meyers et al., 1998; Chi et al., 2003), showed that the observed anatomical malformations in these models are due to the mis-specification of the IsO.

\section{Shh signaling pathway}

Since their isolation in the early 1990's (Lee et al., 1992; Echelard et al., 1993; Tashiro et al., 1993) members of the Hedgehog family of intercellular signaling proteins have come to be recognized as key mediators of many fundamental processes in embryonic development. Their activities are central to the growth, patterning and morphogenesis of many different regions within the body plans of vertebrates and insects. Sonic Hedgehog (Shh) is well known as the molecule responsible for the induction and maintenance of ventral neural tube structures. Recent data have shown that ventral neuronal populations react differentially to the amount of this morphogen not only in the spinal cord, but also in more rostral parts of the brain, in particular the development of the different mesencephalic basal nuclei in the absence of Shh (Perez-Balaguer et al. 2009).

Shh is proteolytically cleaved to produce two secreted proteins, a $19 \mathrm{kDa} \mathrm{N}$-terminal protein (N-Shh) that mediates all signaling activities in vertebrates and invertebrates (for review see Hammerschmidt et al., 1996, 1997) and a 25 kDa Cterminal protein (C-Shh) which possesses protease activity (Porter et al., 1995; Porter et al., 1996). N-Shh is further modified by addition of a cholesterol moiety to the C-terminal amino acid and a palmitoyl group to the $\mathrm{N}$-terminal of the processed N-Shh (Chamoun et al., 2001).

At the cell surface, Shh binds with high affinity to patched (Ptc), a 12-transmembrane protein. Binding of Shh to Ptc prevents the normal inhibition of smoothened (Smo), a 7transmembrane protein (Alcedo et al., 1996; Van den Heuvel and Ingham, 1996; Hammerschmidt and McMahon, 1998; Hynes et al., 2000). Further regulators of the pathway, which act at the surface of cells responding to Shh, have been identified in the vertebrate CNS. Hedgehog-interacting protein (Hip) is a type I transmembrane protein which attenuates Shh signaling by binding N-Shh with an affinity similar to that of Ptc1 (Chuang and McMahon, 1999), whereas vitronectin, an extracellular matrix glycoprotein, enhances Shh activity during motor-neuron differentiation, by also binding Shh directly (Pons and Marti, 2000).

Within the nucleus of the responding cell, zinc-finger transcription factors of the Ci/Gli family act at the last known step of the Shh signal transduction pathway (Hynes et al., 1997; Ruiz i Altaba, 1998). A region specific combinatory effect of Gli2 activation and Gli3 repression by Shh in different areas of the neural tube determines regional activity of Shh signal in neural patterning and growth (Blaess et al., 2006; Zervas et al. 2004).

\section{FGF signaling pathway}

We have already mentioned that at early stages of development, Fgf8 is required to maintain the expression of genes which play a role in neural tube patterning. Moreover, it is essential for cell survival, as evidenced by the finding that inactivation of Fgf8 in the early neural plate causes extensive cell death throughout the mesencephalon and rostral hindbrain, resulting in full deletion of the midbrain and cerebellum. Interestingly, when Fgf8 expression is modestly reduced, rather than eliminated, the rostralmost portion of the midbrain is spared and appears normal, whereas the remaining dorsal midbrain, isthmus and cerebellum are absent (Chi et al., 2003; Partanen, 2007). This suggests that there are regional differences in sensitivity to FGF signaling within the mesencephalon and/or rhombencephalon.

FGF signaling is mediated via receptor tyrosinekinases(RTKs). These transmembrane FGF receptors (FGFRs) 
activate signaling cascades including the phosphatidylinositol3 kinase (PI3K) and Ras-ERK pathways (MAPK) (for review see Martin, 1998; Niehrs and Meinhardt, 2002; Tsang and Dawid, 2004). The expression of molecules such as Mkp3/Sef and those belonging to the sprouty (Spry) family are induced by Fgf8 expression in the organizers (Fig. 5) and may determine the spatial reduction of Fgf8 activity in a gradient manner by interaction with the intracellular mechanism of the MAP kinase cascade (Furthauer et al., 2002; Tsang and Dawid, 2004; Echevarria et al., 2005a; Vieira et al., 2005; for review see Echevarria et al., 2005b). In particular, the negative feedback modulator of Fgf8 signaling, Mkp3, selectively inactivates the ERK1/2 class of MAP kinases by dephosphorylation leading to catalytic inactivation. It thus prevents translocation into the nucleus, resulting in inhibition of ERK1/2-dependent transcription (Camps et al., 1998; Groom et al., 1996; Muda et al., 1996).

Thus, FGFs activate signal from the organizer regions and present a gradient-like distribution in the extracellular compartment. This gradient, acting trough FGF receptors, activates intracellular transduction pathways which are required for cellautonomous control of Fgf8 expression and for the activation of expression of multiple genes necessary for a variety of developmental processes, including cell fate decisions, determination of axial polarity and promotion of cell survival.

The morphogenetic activity of the Is $\mathrm{O}$ is then a consequence of specific molecular expression patterns, which regulate the differential specification of neuroepithelial territories. The decreasing gradient of Fgf8 concentration in the alar plate is fundamental for cell survival and the differential development of cerebellar, isthmic and mesencephalic regions (Basson et al., 2008; Chi et al., 2003; Nakamura et al., 2005). In the basal plate, Fgf8 concentration gradients are the key players in cell survival and, together with Shh, regulate caudal serotoninergic and rostral dopaminergic fates in cellular progenitors (Fig. 5), as well as the localization and development of other basal derivatives, such as noradrenergic cells in the locus coeruleus (in the rhombencephalon) and the red nucleus (in the mesencephalic tegmentum) (Chi et al., 2003; Puelles and Rubenstein, 2003,2004; Prakash et al., 2006; Prakash and Wurst, 2006). Finally, mesencephalic and diencephalic epithelia are receptive to Fgf8 signal (Martinez et al., 1991 and 1999; Crossley et al., 1996), which may regulate gene expression and neuroepithelial polarity in the alar plate of these territories (Vieira et al., 2006).

\section{Conclusion}

The overall organization of the vertebrate CNS is largely due to set down by the concerted action of morphogenetic signals acting during the early gastrula stage of embryonic development. Primary neural induction and fundamental antero-posterior or dorso-ventral regionalization of the early neural tube is due to the activity of the "primary organizer". Slightly later in development, local signaling centers in the neuroepithelium, known as "secondary organizers", refine the antero-posterior specification of the three main domains in the brain primordium: forebrain, midbrain and hindbrain. Additionally, the morphogenetic activity of these secondary organizers controls the polarity and the generation of neural sub-regions inside these main regions. Morphogenetic organizers developed in specific domains of the neuroepithelium as a consequence of interactions between two differently pre-specified zones. They confer positional identity by secreting a graded concentration of signal, which triggers concentration-specific genetic cascades. The fact that Gbx2 and Otx2, as well as prechordal and epichordal genes are expressed prior to Fgf8 and Shh in the Isthmic and ZLI organizers, respectively, would support this postulate.

\section{Acknowledgements}

We thank M Ródenas and F. Almagro for technical assistance in the publications cited in this manuscript. This work was supported by grants from the Spanish MEC (BFU2008-00588 and SAF2008-01004), EU LSHG-CT-2004-512003 (EUREXPRESS-II), EC- CONSOLIDER CSD2007-00023, Imagenio2010. D. Echevarria has a contract of Program Ramón y Cajal (RYC-2004-00320), and is supported by the Spanish Ministry of Health, Instituto de Salud Carlos III-CIBERSAM. C. Vieira was a pre-doctoral fellow of the Gulbenkian PhD Program in Biomedicine supported by a grant from the FCT/MCES. The authors would also like to express their thanks to the Agency Quattro (http:// www.euskalnet.net/acts) for having corrected the English grammar of this paper.

\section{References}

ACAMPORA, D., MAZAN, S., LALLEMAND, Y., AVANTAGGIATO, V., MAURY, M., SIMEONE, A. and BRULET, P. (1995). Forebrain and midbrain regions are deleted in Otx2-/- mutants due to a defective anterior neuroectoderm specification during gastrulation. Development 121: 3279-3290.

ACAMPORA, D., AVANTAGgIATO, V., TUORTO, F. and SIMEONE, A. (1997). Genetic control of brain morphogenesis through Otx gene dosage requirement. Development 124: 3639-3650.

ALCEDO, J., AYZENZON, M., VON OHLEN, T., NOLL, M. and HOOPER, J. E. (1996).The Drosophila smoothened gene encodes a seven-pass membrane protein, a putative receptor for the hedgehog signal. Cell 86: 221-232.

ALVARADO-MALLART, R. M. (1993). Fate and potentialities of the avian mesencephalic/metencephalic neuroepithelium. J Neurobiol 24: 1341-1355.

ALVAREZ-BOLADO, G., ROSENFELD, M. G., and SWANSON, L. W. (1995). Model of forebrain regionalization based on spatiotemporal patterns of $\mathrm{POU}$ III homeobox gene expression, birthdates, and morphological features. J Comp Neurol 355: 237-295.

ANG, S. L., and ROSSANT, J. (1993). Anterior mesendoderm induces mouse Engrailed genes in explant cultures. Development 118: 139-149.

ANG, S. L., CONLON, R. A., JIN, O. and ROSSANT, J. (1994). Positive and negative signals from mesoderm regulate the expression of mouse Otx2 in ectoderm explants. Development 120: 2979-2989.

ANG, S.L., JIN, O., RHINN, M., DAIGLE, N., STEVENSON, L. and ROSSANT, J. (1996). A targeted mouse Otx2 mutation leads to severe defects in gastrulation and formation of axial mesoderm and to deletion of rostral brain. Development 122: 243-252.

AROCA, P. and PUELLES, L. (2005). Postulated boundaries and differential fate in the developing rostral hindbrain. Brain Res Brain Res Rev. 49: 179-190.

BALLY-CUIF, L., GULISANO, M., BROCCOLI, V. and BONCINELLI, E. (1995). C-otx2 is expressed in two different phases of gastrulation and is sensitive to retinoic acid treatment in chick embryo. Mech Dev 49: 49-63.

BASLER, K., EDLUND, T., JESSELL, T. M. and YAMADA, T. (1993). Control of cell pattern in the neural tube: regulation of cell differentiation by dorsalin-1, a novel TGF beta family member. Cell 73: 687-702.

BASSON, M. A., ECHEVARRIA, D., AHN, C. P., SUDAROV, A., JOYNER, A. L., MASON, I. J., MARTINEZ, S. and MARTIN, G. R. (2008). Specific regions within the embryonic midbrain and cerebellum require different levels of FGF signaling during development. Development 135: 889-898.

BLAESS, S., CORRALES, J. D. and JOYNER, A. L. (2006). Sonic hedgehog regulates Gli activator and repressor functions with spatial and temporal 
precision in the mid/hindbrain region. Development 133: 1799-1809.

BLUMBERG, B., BOLADO, J. JR., MORENO, T. A., KINTNER, C., EVANS, R. M. and PAPALOPULU, N. (1997). An essential role for retinoid signaling in anteroposterior neural patterning. Development 124: 373-379.

BOUWMEESTER, T., KIM, S., SASAI, Y., LU, B. and DE ROBERTIS, E. M. (1996). Cerberus is a head-inducing secreted factor expressed in the anterior endoderm of Spemann's organizer. Nature 382: 595-601.

BRAND, M., HEISENBERG, C. P., WARGA, R. M., PELEGRI, F., KARLSTROM, R. O., BEUCHLE, D., PICKER, A., JIANG, Y. J., FURUTANI-SEIKI, M., VAN EEDEN, F. J., GRANATO, M., HAFFTER, P., HAMMERSCHMIDT, M., KANE, D. A., KELSH, R. N., MULLINS, M. C., ODENTHAL, J. and NUSSLEINVOLHARD, C. (1996). Mutations affecting development of the midline and general body shape during zebrafish embryogenesis. Development 123: 129142.

BROCCOLI, V., BONCINELLI, E. and WURST, W. (1999). The caudal limit of Otx2 expression positions the isthmic organizer. Nature 401: 164-168.

BUlfone, A., PUElLES, L., PORTEUS, M. H., FROHMAN, M. A., MARTìN, G. R. and RUBENSTEIN, J. L. (1993). Spatially restricted expression of DIx-1, DIx-2 (Tes-1), Gbx-2, and Wnt-3 in the embryonic day 12.5 mouse forebrain defines potential transverse and longitudinal segmental boundaries. J Neurosci 13: 3155-3172.

CAMBRONERO, F. and PUELLES, L. (2000). Rostrocaudal nuclear relationships in the avian medulla oblongata: a fate map with quail chick chimeras. J Comp Neurol 427: 522-545.

CAMPS, M., NICHOLS, A., GILLIERON, C., ANTONSSON, B., MUDA, M., CHABERT, C., BOSCHERT, U. and ARKINSTALL, S. (1998). Catalytic activation of the phosphatase MKP-3 by ERK2 mitogen-activated protein kinase. Science 280: 1262-1265.

CHAMOUN, Z., MANN, R. K., NELLEN, D., VON KESSLER, D. P., BELLOTTO, M., BEACHY, P. A. and BASLER, K. (2001). Skinny hedgehog, an acyltransferase required for palmitoylation and activity of the hedgehog signal. Science 293: 2080-2084.

CHI, C. L., MARTINEZ, S., WURST, W. and MARTIN, G.R. (2003). The isthmic organizer signal FGF8 is required for cell survival in the prospective midbrain and cerebellum. Development 130: 2633-2644.

CHIANG, C., LITINGTUNG, Y., LEE, E., YOUNG, K. E., CORDEN, J. L., WESTPHAL, H. and BEACHY, P. A. (1996). Cyclopia and defective axial patterning in mice lacking Sonic hedgehog gene function. Nature 383: 407413.

CHUANG, P. T. and MCMAHON, A. P. (1999). Vertebrate Hedgehog signaling modulated by induction of a Hedgehog-binding protein. Nature 397: 617-621.

COBOS, I., PUELLES, L. and MARTINEZ, S. (2001). The avian telencephalic subpallium originates inhibitory neurons that invade tangentially the pallium (dorsal ventricular ridge and cortical areas). Dev Biol 239: 30-45.

COLAS, J. F. and SCHOENWOLF G. C. (2001). Towards a cellular and molecular understanding of neurulation. Dev Dyn 221: 117-145.

COX, W. G. and HEMMATI-BRIVANLOU, A. (1995). Caudalization of neural fate by tissue recombination and bFGF. Development 121: 4349-4358.

CROSSLEY, P. H. and MARTIN, G. R. (1995). The mouse Fgf8 gene encodes a family of polypeptides and is expressed in regions that direct outgrowth and patterning in the developing embryo. Development 121: 439-451.

CROSSLEY, P. H., MARTINEZ, S. and MARTIN, G. R. (1996) Midbrain development induced by FGF8 in the chick embryo. Nature 380: 66-68.

CROSSLEY, P. H., MARTINEZ, S., OHKUBO, Y. and RUBENSTEIN, J. L. (2001). Coordinate expression of Fgf8, Otx2, Bmp4, and Shh in the rostral prosencephalon during development of the telencephalic and optic vesicles. Neuroscience 108: 183-206.

DARNELL, D. K. and SCHOENWOLF, G. C. (1997). Vertical induction of engrailed-2 and other region-specific markers in the early chick embryo. Dev Dyn 209: 45-58.

DAVIS, C. A. and JOYNER, A. L. (1988). Expression patterns of the homeo boxcontaining genes En-1 and En-2 and the proto-oncogene int-1 diverge during mouse development. Genes Dev 2: 1736-1744.

DICKINSON, M. E., SELLECK, M. A., MCMAHON, A. P. and BRONNERFRASER, M. (1995). Dorsalization of the neural tube by the non-neural ectoderm. Development 121: 2099-2106.
DONIACH, T. (1993). Planar and vertical induction of anteroposterior pattern during the development of the amphibian central nervous system. J Neurobiol 24: 1256-1275.

DURSTON, A. J., TIMMERMANS, J. P., HAGE, W. J., HENDRIKS, H. F., DE VRIES, N. J., HEIDEVELD, M. and NIEUWKOOP, P. D. (1989). Retinoic acid causes an anteroposterior transformation in the developing central nervous system. Nature 340: 140-144.

ECHELARD, Y., EPSTEIN, D. J., ST-JACQUES, B., SHEN, L., MOHLER, J., MCMAHON, J. A. and MCMAHON, A. P. (1993). Sonic hedgehog, a member of a family of putative signaling molecules, is implicated in the regulation of CNS polarity. Cell 75: 1417-1430.

ECHEVARRIA, D., BELO, J. A. and MARTINEZ, S. (2005a). Modulation of Fgf8 activity during vertebrate brain development. Brain Res Rev 49: 150-157.

ECHEVARRIA, D., MARTINEZ, S., MARQUES, S., LUCAS-TEIXEIRA, V., and BELO, J. A. (2005b). Mkp3 is a negative feedback modulator of Fgf8 signaling in the mammalian isthmic organizer. Dev Biol 277: 114-128.

ECHEVARRIA, D., VIEIRA, C., GIMENO, L. and MARTINEZ, S. (2003). Neuroepithelial secondary organizers and cell fate specification in the developing brain. Brain Res Rev 43: 179-191.

ECHEVARRIA, D., VIEIRA C. and MARTINEZS. (2001). Mammalian neural tube grafting experiments: an in vitro system for Mouse experimental embryology. Int J Dev Biol 45: 895-902.

ERICSON, J., MORTON, S., KAWAKAMI, A., ROELINK, H. and JESSELL, T. M. (1996). Two critical periods of Sonic Hedgehog signaling required for the specification of motor neuron identity. Cell 87: 661-673.

ERICSON, J., MUHR, J., PLACZEK, M., LINTS, T., JESSELL, T. M. and EDLUND, T. (1995). Sonic hedgehog induces the differentiation of ventral forebrain neurons: a common signal for ventral patterning within the neural tube. Cell 81: 747-756.

FAN, C. M., KUWANA, E., BULFONE, A., FLETCHER, C. F., COPELAND, N. G., JENKINS, N. A., CREWS, S., MARTINEZ, S., PUELLES, L., RUBENSTEIN, J. L. R. and TESSIER-LAVIGNE, M. (1996). Expression patterns of two murine homologs of Drosophila single-minded suggest possible roles in embryonic patterning and in the pathogenesis of Down syndrome. Mol Cell Neurosci 7: 1-16.

FAN, H. and KHAVARI, P. A. (1999). Sonic hedgehog opposes epithelial cell cycle arrest. J Cell Biol 147: 71-76.

FIGDOR, M. C. and STERN, C. D. (1993). Segmental organization of embryonic diencephalon. Nature 363. 630-634.

FUKUCHI-SHIMOGORI, T. and GROVE, E. A. (2001). Neocortex patterning by the secreted signaling molecule FGF8. Science 294: 1071-1074.

FURTHAUER, M., LIN, W., ANG, S. L., THISSE, B. and THISSE, C. (2002). Sef is a feedback-induced antagonist of Ras/MAPK-mediated FGF signaling. Nat Cell Biol 4: 170-174.

GARCIA-CALERO, E, FERNANDEZ-GARRE P, MARTINEZ S and PUELLES L. (2008). Early mammillary pouch specification in the course of prechordal ventralization of the forebrain tegmentum. Dev Biol 320: 366-377.

GARCIA-LOPEZ, R., VIEIRA, C., ECHEVARRIA, D. and MARTINEZ, S. (2004). Fate map of the diencephalon and the zona limitans at the 10-somites stage in chick embryos. Dev Biol 268: 514-530.

GARDA, A. L., ECHEVARRIA, D. and MARTINEZ, S. (2001). Neuroepithelial coexpression of Gbx2 and Otx2 precedes Fgf8 expression in the isthmic organizer. Mech Dev 101: 111-118.

GAREL, S., MARIN, F., MATtEI, M. G., VESQUE, C., VINCENT, A. and CHARNAY, P. (1997). Family of Ebf/Olf-1-related genes potentially involved in neuronal differentiation and regional specification in the central nervous system. Dev Dyn 210: 191-205.

GIMENO, L., BRULET, P. and MARTINEZ, S. (2003). Study of Fgf15 gene expression in developing mouse brain. Gene Expr Patterns 3: 473-481.

GIMENO, L., HASHEMI, R., BRULET, P. and MARTINEZ, S. (2002). Analysis of Fgf15 expression pattern in the mouse neural tube. Brain Res Bull 57: 297299.

GONZALEZ, G., PUELLES, L. and MEDINA, L. (2002). Organization of the mouse dorsal thalamus based on topology, calretinin immunostaining, and gene expression. Brain Res Bull 57: 439-442. 
GROOM, L. A., SNEDDON, A. A., ALESSI, D. R., DOWD, S. and KEYSE, S. M. (1996). Differential regulation of the MAP, SAP and RK/p38 kinases by Pyst1, a novel cytosolic dual-specificity phosphatase. EMBO J. 15: 3621-3632.

GUO, C., QIU, H. Y., HUANG, Y., YANG, R. Q., CHEN, S. D., JONSON, R. L., CHEN, Z. F., and Ding, Y. Q. (2007). Lmx1b is essential for Fgf8 and Wnt1 expression in the isthmic organizer during tectum and cerebellum development in mice. Development 134: 317-325.

HAMMERSCHMIDT, M. and MCMAHON, A. P. (1998). The effect of pertussis toxin on zebrafish development: a possible role for inhibitory G-proteins in hedgehog signaling. Dev Biol 194: 166-171.

HAMMERSCHMIDT, M., BITGOOD, M. J. and MCMAHON, A. P. (1996). Protein kinase $A$ is a common negative regulator of Hedgehog signaling in the vertebrate embryo. Genes Dev 10: 647-658.

HAMMERSCHMIDT, M., BROOK, A. and MCMAHON, A. P. (1997). The world according to hedgehog. Trends Genet 13: 14-21.

HASHIMOTO-TORII, K., MOTOYAMA, J., HUI, C. C., KUROIWA, A., NAKAFUKU, M. and SHIMAMURA, K. (2003). Differential activities of Sonic hedgehog mediated by Gli transcription factors define distinct neuronal subtypes in the dorsal thalamus. Mech Dev 120: 1097-1111.

HEMMATI-BRIVANLOU, A. and MELTON, D. (1997). Vertebrate neural induction. Annu Rev Neurosci 20: 43-60.

HEMMATI-BRIVANLOU, A., KELLY, O. G. and MELTON, D. A. (1994). Follistatin, an antagonist of activin, is expressed in the Spemann organizer and displays direct neuralizing activity. Cell 77: 283-295.

HIDALGO-SANCHEZ, M. and ALVARADO-MALLART, R. M. (2002). Temporal sequence of gene expression leading caudal prosencephalon to develop a midbrain/hindbrain phenotype. Dev Dyn 223: 141-147.

HIDALGO-SANCHEZ, M., ALVARADO-MALLART, R., and ALVAREZ, I. S. (2000). Pax2, Otx2, Gbx2 and Fgf8 expression in early otic vesicle development. Mech Dev 95: 225-229.

HIDALGO-SANCHEZ, M., MILLET, S., BLOCH-GALLEGO, E. and ALVARADOMALLART, R. M. (2005). Specification of the meso-isthmo-cerebellar region: the Otx2/Gbx2 boundary. Brain Res Rev. 49: 134-149.

HOOIVELD, M. H, MORGAN, R., IN DER RIEDEN, P., HOUTZAGER, E., PANNESE, M., DAMEN, K., BONCINELLI, E. and DURSTON, A. J. (1999). Novel interactions between vertebrate Hox genes. Int J Dev Biol 43: 665-674.

HOUART, C., WESTERFIELD, M. and WILSON, S. W. (1998). A small population of anterior cells patterns the forebrain during zebrafish gastrulation. Nature 391: 788-792.

HYNES, M., PORTER, J. A., CHIANG, C., CHANG, D., TESSIER-LAVIGNE, M., BEACHY, P. A. and ROSENTHAL, A. (1995a). Induction of midbrain dopaminergic neurons by Sonic hedgehog. Neuron 15: 35-44.

HYNES, M., POULSEN, K., TESSIER-LAVIGNE, M. and ROSENTHAL, A. (1995b). Control of neuronal diversity by the floor plate: contact-mediated induction of midbrain dopaminergic neurons. Cell 80: 95-101.

HYNES, M., STONE, D. M., DOWD, M., PITTS-MEEK, S., GODDARD, A., GURNEY, A. and ROSENTHAL, A. (1997). Control of cell pattern in the neural tube by the zinc finger transcription factor and oncogene Gli-1. Neuron 19: 1526.

HYNES, M., YE, W., WANG, K., STONE, D., MURONE, M., SAUVAGE, F. and ROSENTHAL, A. (2000). The seven-transmembrane receptor smoothened cell-autonomously induces multiple ventral cell types. Nat Neurosci 3: 41-46.

IRVING, C. and MASON, I. (2000). Signaling by FGF8 from the isthmus patterns anterior hindbrain and establishes the anterior limit of Hox gene expression. Development 127: 177-186.

ISHIBASHI, M. and MCMAHON, A. P. (2002). A sonic hedgehog-dependent signaling relay regulates growth of diencephalic and mesencephalic primordia in the early mouse embryo. Development 129: 4807-4819.

JOYNER, A. L. (1996). Engrailed, Wnt and Pax genes regulate midbrainhindbrain development. Trends Genet 12: 15-20.

JOYNER, A. L., LIU, A. and MILLET, S. (2000). Otx2, Gbx2 and Fgf8 interact to position and maintain a mid-hindbrain organizer. Curr Opin Cell Biol 12: 736741.

KATAHIRA, T., SATO, T., SUGIYAMA, S., OKAFUJI, T., ARAKI, I., FUNAHASHI, J. and NAKAMURA, H. (2000). Interaction between Otx2 and Gbx2 defines the organizing center for the optic tectum. Mech Dev 91: 43-52.

KELLER, R., SHIH, J., SATER, A. K. and MORENO, C. (1992). Planar induction of convergence and extension of the neural plate by the organizer of Xenopus. Dev Dyn 193: 218-234.

KELLY, O. G., and MELTON, D. A. (1995). Induction and patterning of the vertebrate nervous system. Trends Genet 11: 273-278.

KIECKER, C. and LUMSDEN, A. (2004). Hedgehog signaling from the ZLI regulates diencephalic regional identity. Nat Neurosci 7: 1242-1249.

KOBAYASHI, D., KOBAYASHI, M., MATSUMOTO, K., OGURA, T., NAKAFUKU, $M$. and SHIMAMURA, K. (2002). Early subdivisions in the neural plate define distinct competence for inductive signals. Development 129: 83-93.

LAMB, T. M. and HARLAND, R. M. (1995). Fibroblast growth factor is a direct neural inducer, which combined with noggin generates anterior-posterior neural pattern. Development 121: 3627-3636.

LAMB, T. M., KNECHT, A. K., SMITH, W. C., STACHEL, S. E., ECONOMIDES, A. N., STAHL, N., YANCOPOLOUS, G. D. and HARLAND, R. M. (1993). Neural induction by the secreted polypeptide noggin. Science 262: 713-718.

LEE, J. J., VON KESSLER, D. P., PARKS, S. and BEACHY, P. A. (1992) Secretion and localized transcription suggest a role in positional signaling for products of the segmentation gene hedgehog. Cell 71: 33-50.

LEIKOLA, A. (1976). Hensen's node - the 'organizer' of the amniote embryo. Experientia 32: 269-277.

LI, J. Y. and JOYNER, A. L. (2001). Otx2 and Gbx2 are required for refinement and not induction of mid-hindbrain gene expression. Development 128: 49794991.

LIEM, K. F. JR., TREMML, G., ROELINK, H. and JESSELL, T. M. (1995). Dorsal differentiation of neural plate cells induced by BMP-mediated signals from epidermal ectoderm. Cell 82: 969-979.

LIGUORI, G. L., ECHEVARRIA, D., IMPROTA, R., SIGNORE, M., ADAMSON, E., MARTINEZ, S. and PERSICO, M. G. (2003). Anterior neural plate regionalization in cripto null mutant mouse embryos in the absence of node and primitive streak. Dev Biol 264: 537-549.

LIGUORI, G. L., ECHEVARRIA, D., BONILLA, S., D'ANDREA, D., LIGUERO, A., PERSICO, M. G. and MARTINEZ, S. (2009). Characterization of the functional properties of the neuroectoderm in mouse Cripto -/- embryos showing severe gastrulation defects. Int. J. Dev. Biol. 53: 549 - 557. (DOI: 10.1387/ ijdb.082650gl)

LINKER, C., DE ALMEIDA, I., PAPANAYOTOU, C., STOWER, M., SABADO, V., GHORANI, E., STREIT, A., MAYOR, R. and STERN, C. D. (2009). Cell communication with the neural plate is required for induction of neural markers by BMP inhibition: evidence for homeogenetic induction and implications for Xenopus animal cap and chick explant assays. Dev Biol, DOI:10.1016 j.ydbio.2008.12.034

LIU, A. O and JOYNER, A. L. (2001). EN and GBX2 play essential roles downstream of FGF8 in patterning the mouse mid/hindbrain region. Development 128: 181-191.

MARIN, F. and PUELLES, L. (1994). Patterning of the embryonic avian midbrain after experimental inversions: a polarizing activity from the isthmus. Dev Biol 163: 19-37.

MARTI, E., BUMCROT, D. A., TAKADA, R. and MCMAHON, A. P. (1995). Requirement of $19 \mathrm{~K}$ form of Sonic hedgehog for induction of distinct ventral cell types in CNS explants. Nature 375: 322-325.

MARTIN, G. R. (1998). The roles of FGFs in the early development of vertebrate limbs. Genes Dev 12: 1571-1586.

MARTINEZ, S. (2001). The isthmic organizer and brain regionalization. Int J Dev Biol 45: 367-371.

MARTINEZ, S. and ALVARADO-MALLART, R. M. (1989). Rostral Cerebellum Originates from the Caudal Portion of the So-Called 'Mesencephalic' Vesicle: A Study Using Chick/Quail Chimeras. Eur J Neurosci 1: 549-560.

MARTINEZ, S. and ALVARADO-MALLART, R. M. (1990). Expression of the homeobox Chick-en gene in chick/quail chimeras with inverted mes-metencephalic grafts. Dev Biol 139: 432-436.

MARTINEZ, S. and PUELLES, L. (2000). Neurogenetic compartments of the mouse diencephalon and some characteristic gene expression patterns. Results Probl. Cell Differ 30: 91-106. 
MARTINEZ, S., CROSSLEY, P. H., COBOS, I., RUBENSTEIN, J. L. and MARTIN, G. R. (1999). FGF8 induces formation of an ectopic isthmic organizer and isthmocerebellar development via a repressive effect on Otx2 expression. Development 126: 1189-1200.

MARTINEZ, S., MARIN, F., NIETO, M. A. and PUELLES, L. (1995). Induction of ectopic engrailed expression and fate change in avian rhombomeres: intersegmental boundaries as barriers. Mech Dev 51: 289-303.

MARTINEZ, S., WASSEF, M. and ALVARADO-MALLART, R. M. (1991). Induction of a mesencephalic phenotype in the 2-day-old chick prosencephalon is preceded by the early expression of the homeobox gene en. Neuron 6: 971 981.

MARTINEZ-BARBERA, J. P., SIGNORE, M., BOYL, P. P., PUELLES, E., ACAMPORA, D., GOGOI, R., SCHUBERT, F., LUMSDEN, A. and SIMEONE, A. (2001). Regionalisation of anterior neuroectoderm and its competence in responding to forebrain and midbrain inducing activities depend on mutual antagonism between OTX2 and GBX2. Development 128: 4789-4800.

MARTINEZ-DE-LA-TORRE, M., GARDA, A. L., PUELLES, E. and PUELLES, L. (2002). Gbx2 expression in the late embryonic chick dorsal thalamus. Brain Res Bull 57: 435-438.

MATSUO, I., KURATANI, S., KIMURA, C., TAKEDA, N. and AIZAWA, S. (1995). Mouse Otx2 functions in the formation and patterning of rostral head. Genes Dev 9: 2646-2658.

MCMAHON, A. P. and BRADLEY, A. (1990). The Wnt-1 (int-1) proto-oncogene is required for development of a large region of the mouse brain. Cell 62: 1073-1085.

MEINHARDT, H. (1983) Cell determination boundaries as organizing regions for secondary embryonic fields. Dev Biol 96: 375-85.

MEYERS, E. N., LEWANDOSKI, M. and MARTIN, G. R. (1998). An Fgf8 mutant allelic series generated by Cre- and Flp-mediated recombination. Nat Genet 18: $136-141$

MILLEN, K. J., WURST, W., HERRUP, K. and JOYNER, A. L. (1994). Abnormal embryonic cerebellar development and patterning of postnatal foliation in two mouse Engrailed-2 mutants. Development 120: 695-706.

MILLET, S., CAMPBELL, K., EPSTEIN, D. J., LOSOS, K., HARRIS, E. and JOYNER, A. L. (1999)..A role for Gbx2 in repression of Otx2 and positioning the $\mathrm{mid} /$ hindbrain organizer. Nature 401: 161-164.

MIYASHITA-LIN, E. M., HEVNER, R., WASSARMAN, K. M., MARTINEZ, S. and RUBENSTEIN, J. L. (1999). Early neocortical regionalization in the absence of thalamic innervation. Science 285: 906-909.

MUDA, M., BOSCHERT, U., DICKINSON, R., MARTINOU, J. C., MARTINOU, I., CAMPS, M., SCHLEGEL, W. and ARKINSTALL, S. (1996). MKP-3, a novel cytosolic protein-tyrosine phosphatase that exemplifies a new class of mitogen-activated protein kinase phosphatase. J Biol Chem 271: 4319-4326.

NAKAMURA, H., KATAHIRA, T., MATSUNAGA, E. and SATO, T. (2005). Isthmus organizer for midbrain and hindbrain development. Brain Res Brain Res Rev 49: 120-126.

NIEHRS, C. and MEINHARDT, H. (2002). Modular feedback. Nature 417: 35-36.

PAPALOPULU, N., CLARKE, J. D., BRADLEY, L., WILKINSON, D., KRUMLAUF, R. and HOLDER, N. (1991). Retinoic acid causes abnormal development and segmental patterning of the anterior hindbrain in Xenopus embryos. Development 113: 1145-1158.

PARTANEN, J. (2007). FGF signalling pathways in development of the midbrain and anterior hindbrain. $J$ Neurochem 101: 1185-1193.

PEARSON, J. C., LEMONS, D., and MCGINNIS, W. (2005). Modulating Hox gene functions during animal body patterning. Nat Rev Genet 6: 893-904.

PEREZ-BALAGUER, A., PUELLES, E., WURST, W. and MARTINEZ, S. (2009). Shh dependent and independent maintenance of basal midbrain. Mech Dev. 126: 301-13.

PLACZEK, M., JESSELL, T. M. and DODD, J. (1993). Induction of floor plate differentiation by contact-dependent, homeogenetic signals. Development 117: 205-218.

POMBERO, A. and MARTINEZ, S. (2009). Telencephalic morphogenesis during the process of neurulation: an experimental study using quail-chick chimeras. $J$ Comp Neurol 512: 784-797.

PONS, S. and MARTI, E. (2000). Sonic hedgehog synergizes with the extracel- lular matrix protein vitronectin to induce spinal motor neuron differentiation. Development 127: 333-342.

PORTER, J. A., EKKER, S. C., PARK, W. J., VON KESSLER, D. P., YOUNG, K. E., CHEN, C. H., MA, Y., WOODS, A. S., COTTER, R. J., KOONIN, E. V. and BEACHY, P. A. (1996). Hedgehog patterning activity: role of a lipophylic modification mediated by the carboxy-terminal autoprocessing domain. Cell 86: 21-34

PORTER, J. A., VON KESSLER, D. P., EKKER, S. C., YOUNG, K. E., LEE, J. J., MOSES, K. and BEACHY, P. A. (1995). The product of hedgehog autoproteolytic cleavage active in local and long-range signaling. Nature 374: 363-366.

PRAKASH, N., and WURST, W. (2006). Genetic networks controlling the development of midbrain dopaminergic neurons. J Physiol 575: 403-410.

PRAKASH, N., BRODSKI, C., NASERKE, T., PUELLES, E., GOGOI, R., HALL, A., PANHUYSEN, M., ECHEVARRIA, D., SUSSEL, L., WEISENHORN, D. M., MARTINEZ, S., ARENAS, E., SIMEONE, A. and WURST, W. (2006). A Wnt1-regulated genetic network controls the identity and fate of midbraindopaminergic progenitors in vivo. Development 133: 89-98.

PRICE, M., LAZZARO, D., POHL, T., MATTEI, M.G., RUTHER, U., OLIVO, J.C., DUBOULE, D. and DI LAURO, R. (1992). Regional expression of the homeobox gene Nkx-2.2 in the developing mammalian forebrain. Neuron 8: 241-255.

PROCHIANTZ, A. (1999). Homeodomain-derived peptides. In and out of the cells. Ann N Y Acad Sci 886: 172-179.

PUELLES, L. (1995). A segmental morphological paradigm for understanding vertebrate forebrains. Brain Behav Evol 46: 319-337.

PUELLES, L., MARTINEZ, S., MARTINEZ DE LA TORRE, M. and RUBENSTEIN, J. L. R. (2004). Gene maps and related histogenetic domains in the forebrain and midbrain. The rat nervous system, third edition. Elsevier (Ed G Paxinos). pp. 3-25

PUELLES, L. and RUBENSTEIN, J. L. (1993). Expression patterns of homeobox and other putative regulatory genes in the embryonic mouse forebrain suggest a neuromeric organization. Trends Neurosci 16: 472-479.

PUELLES, L. and RUBENSTEIN, J. L. (2003). Forebrain gene expression domains and the evolving prosomeric model. Trends Neurosci 26: 469-476.

PUELLES, L., AMAT, J. A. and MARTINEZ-DE-LA-TORRE, M. (1987). Segmentrelated, mosaic neurogenetic pattern in the forebrain and mesencephalon of early chick embryos: I. Topography of AChE-positive neuroblasts up to stage HH18. J Comp Neurol 266: 247-268.

QIU, M., SHIMAMURA, K., SUSSEL, L., CHEN, S. and RUBENSTEIN, J. L. (1998). Control of anteroposterior and dorsoventral domains of Nkx-6.1 gene expression relative to other Nkx genes during vertebrate CNS development. Mech Dev: 72: 77-88.

RALLU, M., MACHOLD, R., GAIANO, N., CORBIN, J. G., MCMAHON, A. P. and FISHELL, G. (2002). Dorsoventral patterning is established in the telencephalon of mutants lacking both Gli3 and Hedgehog signaling. Development 129: 4963-4974.

ROELINK, H., AUGSBURGER, A., HEEMSKERK, J., KORZH, V., NORLIN, S., RUIZ I ALTABA, A., TANABE, Y., PLACZEK, M., EDLUND, T., JESSELL, T. M., et al. (1994). Floor plate and motor neuron induction by vhh-1, a vertebrate homolog of hedgehog expressed by the notochord. Cell 76: 761 . 775 .

ROELINK, H., PORTER, J. A., CHIANG, C., TANABE, Y., CHANG, D. T., BEACHY, P. A. and JESSELL, T. M. (1995). Floor plate and motor neuron induction by different concentrations of the amino-terminal cleavage product of sonic hedgehog autoproteolysis. Cell 81: 445-455.

ROWITCH, D. H., S-JACQUES, B., LEE, S. M., FLAX, J. D., SNYDER, E. Y. and MCMAHON, A. P. (1999). Sonic hedgehog regulates proliferation and inhibits differentiation of CNS precursor cells. J Neurosci. 19: 8954-8965.

RUBENSTEIN, J. L. and PUELLES, L. (1994). Homeobox gene expression during development of the vertebrate brain. Curr Top Dev Biol 29: 1-63.

RUBENSTEIN, J. L. and SHIMAMURA, K. (1997). Regulation of patterning and differentiation in the embryonic vertebrate forebrain. In Neuronal Development (Eds. WM Cowan, TM Jessell, SL Zipurski). Oxford Univ. Press. pp. 356-390.

RUBENSTEIN, J. L., MARTINEZ, S., SHIMAMURA, K. and PUELLES, L. (Eds.) (1994). The embryonic vertebrate forebrain: the prosomeric model. Science 
266: 578-580.

RUBENSTEIN, J. L., SHIMAMURA, K., MARTINEZ, S. and PUELLES, L. (1998). Regionalization of the prosencephalic neural plate. Annu Rev Neurosci 21: 445-477.

RUIZ I ALTABA, A. (1994). Pattern formation in the vertebrate neural plate. Trends Neurosci 17: 233-243.

RUIZ I ALTABA, A. (1998). Combinatorial Gli gene function in floor plate and neuronal inductions by Sonic hedgehog. Development 125: 2203-2212.

RUIZ I ALTABA, A. and JESSELL, T. (1991b). Retinoic acid modifies mesodermal patterning in early Xenopus embryos. Genes Dev 5: 175-187.

RUIZ I ALTABA, A. and JESSELL, T. M. (1991a). Retinoic acid modifies the pattern of cell differentiation in the central nervous system of neurula stage Xenopus embryos. Development 112: 945-958.

SHAWLOT, W. and BEHRINGER, R. R. (1995). Requirement for Lim1 in headorganizer function. Nature 374: 425-430.

SHIMAMURA, K. and RUBENSTEIN, J. L. (1997). Inductive interactions direct early regionalization of the mouse forebrain. Development 124: 2709-2718.

SHIMAMURA, K., HARTIGAN, D. J., MARTINEZ, S., PUELLES, L. and RUBENSTEIN, J. L. (1995). Longitudinal organization of the anterior neural plate and neural tube. Development 121: 3923-3933.

SIMON, H., HORNBRUCH, A. and LUMSDEN, A. (1995). Independent assignment of antero-posterior and dorso-ventral positional values in the developing chick hindbrain. Curr Biol 5: 205-214.

SMITH, J. L. and SCHOENWOLF, G. C. (1989). Notochordal induction of cell wedging in the chick neural plate and its role in neural tube formation. J Exp Zool 250: 49-62.

SMITH, J. L. and SCHOENWOLF, G. C. (1997). Neurulation: coming to closure. Trends Neurosci 20: 510-517.

SPEMANN, H. and MANGOLD, H. (2001). Induction of embryonic primordia by implantation of organizers from a different species. 1923. Int J Dev Biol 45: $13-38$.

STERN, C. D. (2005). Neural induction: old problem, new findings, yet more questions. Development 132: 2007-2021.

STERN, C. D., CHARITE, J., DESCHAMPS, J., DUBOULE, D., DURSTON, A. J., KMITA, M., NICOLAS, J. F., PALMEIRIM, I., SMITH, J. C., and WOLPERT, L. (2006). Head-tail patterning of the vertebrate embryo: one, two or many unresolved problems? Int J Dev Biol 50: 3-15.

StORM, E. E., GAREL, S., BORELLO, U., HEBERT, J. M., MARTINEZ, S., MCCONNELL, S. K., MARTIN, G. R., and RUBENSTEIN, J. L. (2006). Dosedependent functions of Fgf8 in regulating telencephalic patterning centers. Development 133: 1831-1844.

SUDA, Y., MATSUO, I., KURATANI, S., and AIZAWA, S. (1996). Otx1 function overlaps with Otx2 in development of mouse forebrain and midbrain. Genes Cells 1: 1031-1044.

SUSSEL, L., MARIN, O., KIMURA, S., and RUBENSTEIN, J. L. (1999). Loss of Nkx2.1 homeobox gene function results in a ventral to dorsal molecular respecification within the basal telencephalon: evidence for a transformation of the pallidum into the striatum. Development 126: 3359-3370.

TANABE, Y. and JESSELL, T. M. (1996). Diversity and pattern in the developing spinal cord. Science 274: 1115-1123.

TANABE, Y., ROELINK, H. and JESSELL, T. M. (1995). Induction of motor neurons by Sonic hedgehog is independent of floor plate differentiation. Curr Biol 5: 651-658.

TASHIRO, S., MICHIUE, T., HIGASHIJIMA, S., ZENNO, S., ISHIMARU, S., TAKAHASHI, F., ORIHARA, M., KOJIMA, T. and SAIGO, K. (1993). Structure and expression of hedgehog, a Drosophila segment-polarity gene required for cell-cell communication. Gene 124: 183-189.

THOMAS, K. R. and CAPECCHI, M. R. (1990). Targeted disruption of the murine int-1 proto-oncogene resulting in severe abnormalities in midbrain and cerebellar development. Nature 346: 847-850.

TSANG, M. and DAWID, I.B. (2004). Promotion and attenuation of FGF signaling through the Ras-MAPK pathway. Sci STKE 228: pe17.

URBANEK, P., FETKA, I., MEISLER, M. H. and BUSSLINGER, M. (1997). Cooperation of Pax2 and Pax5 in midbrain and cerebellum development Proc Natl Acad Sci 94: 5703-5708.

VAN DEN HEUVEL, M. and INGHAM, P. W. (1996). smoothened encodes a receptor-like serpentine protein required for hedgehog signaling. Nature 382: 547-551.

VIEIRA, C., GARCIA-LOPEZ, R., and MARTINEZ, S. (2006). Positional regulation of Pax2 expression pattern in mesencephalic and diencephalic alar plate. Neuroscience 137: 7-11

VIEIRA, C., GARDA, A. L., SHIMAMURA, K., and MARTINEZ, S. (2005). Thalamic development induced by Shh in the chick embryo. Dev Biol 284: 351-363.

VOICULESCU, O., BERTOCCHINI, F., WOLPERT, L., KELLER, R. E. and STERN, C. D. (2007). The amniote primitive streak is defined by epithelial cell intercalation befote gastrulation. Nature 449: 1049-1052.

WADDINGTON, C. H. (1933). Induction by the primitive streak and its derivatives in the chick. J Exp Biol 10: 38-48.

WADDINGTON, C. H. (1936). Organizers in mammalian development. Nature 138: 125.

WASSARMAN, K. M., LEWANDOSKI, M., CAMPBELL, K., JOYNER, A. L., RUBENSTEIN, J. L., MARTINEZ, S. and MARTIN, G. R. (1997). Specification of the anterior hindbrain and establishment of a normal mid/hindbrain organizer is dependent on Gbx2 gene function. Development 124: 29232934.

WASSEF, M. and JOYNER, A. L. (1997). Early mesencephalon/metencephalon patterning and development of the cerebellum. Perspect Dev Neurobio/5: 3 16.

WIJGERDE, M., MCMAHON, J. A., RULE, M. and MCMAHON, A. P. (2002). A direct requirement for Hedgehog signaling for normal specification of all ventral progenitor domains in the presumptive mammalian spinal cord Genes Dev 16: 2849-2864

WITTLER, L. and KESSEL, M. (2004). The acquisition of neural fate in the chick. Mech Dev 121: 1031-1042.

WOLTERING, J. M. and DURSTON A. J. (2008). MiR-10 represses HoxB1a and HoxB3a in zebrafish. PLOS ONE 3: e1396.

WURST, W., AUERBACH, A. B. and JOYNER, A. L. (1994). Multiple developmental defects in Engrailed-1 mutant mice: an early mid-hindbrain deletion and patterning defects in forelimbs and sternum. Development 120: 20652075.

XUAN, S., BAPTISTA, C. A., BALAS, G., TAO, W., SOARES, V. C. and LAI, E. (1995). Winged helix transcription factor BF-1 is essential for the development of the cerebral hemispheres. Neuron 14: 1141-1152.

YE, W., SHIMAMURA, K., RUBENSTEIN, J. L., HYNES, M. A. and ROSENTHAL, A. (1998). FGF and Shh signals control dopaminergic and serotonergic cell fate in the anterior neural plate. Cell 93: 755-766.

ZERVAS, M., MILLET, S., AHN, S. and JOYNER, A. L. (2004). Cell behaviors and genetic lineages of the mesencephalon and rhombomere 1. Neuron 43 : 345-357. 
Further Related Reading, published previously in the Int. J. Dev. Biol.

See Special Issue Pattern Formation edited by Michael K. Richardson and Cheng-Ming Chuong at: http://www.ijdb.ehu.es/web/contents.php?vol=53\&issue =5-6

Characterization of the functional properties of the neuroectoderm in mouse Cripto /- embryos showing severe gastrulation defects

Giovanna L. Liguori, Diego Echevarria, Sonia Bonilla, Daniela D'andrea, Annamaria Liguoro, Maria G. Persico, and Salvador Martinez

Int. J. Dev. Biol. (2009) 53: 549-557. (doi: 10.1387/ijdb.082650gl)

Head-tail patterning of the vertebrate embryo: one, two or many unresolved problems? Stern, C.D., Charite, J., Deschamps, J., Duboule, D., Durston, A.J., Kmita, M., Nicolas, J.F., Palmeirim, I., Smith, J.C. and Wolpert, L.

Int. J. Dev. Biol. (2006). 50: 3-15.

Common mechanisms for boundary formation in somitogenesis and brain development: shaping the 'chic' chick

Yoshiko Takahashi

Int. J. Dev. Biol. (2005) 49: 221-230

Isthmus organizer and regionalization of the mesencephalon and metencephalon Harukazu Nakamura and Yuji Watanabe

Int. J. Dev. Biol. (2005) 49: 231-235

Induction of embryonic primordia by implantation of organizers from a different species. 1923.

Spemann $\mathrm{H}$. and Mangold $\mathrm{H}$. (2001)

Int J Dev Biol 45: 13 - 38

The isthmic organizer and brain regionalization

S Martínez

Int. J. Dev. Biol. (2001) 45: 367-371

The role of Otx and Otp genes in brain development D Acampora, M P Postiglione, V Avantaggiato, M Di Bonito and A Simeone Int. J. Dev. Biol. (2000) 44: 669-677

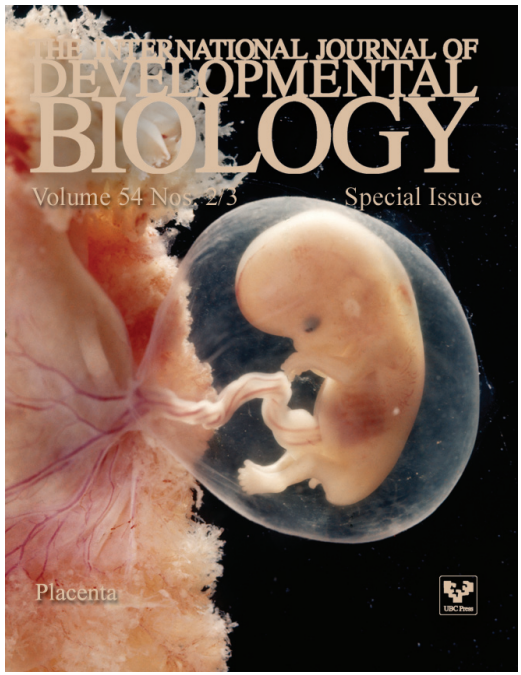

5 yr ISI Impact Factor $(2008)=3.271$

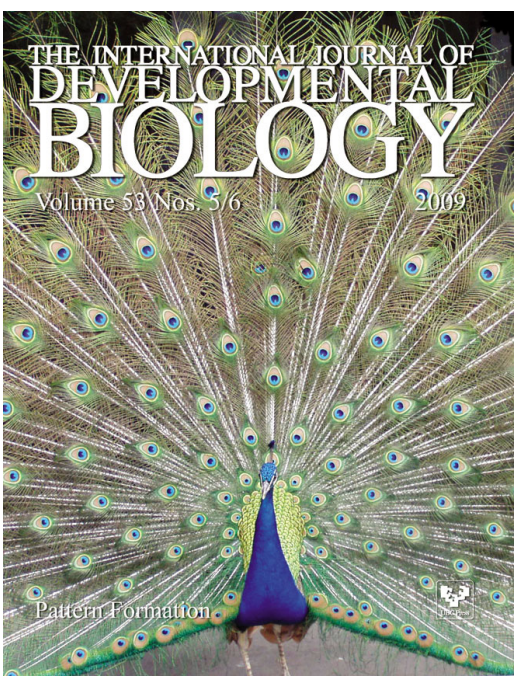

